\title{
Subunit-Specific Modulation of KCNQ Potassium Channels by Src Tyrosine Kinase
}

\author{
Nikita Gamper, James D. Stockand, and Mark S. Shapiro \\ Department of Physiology, University of Texas Health Science Center at San Antonio, San Antonio, Texas 78229
}

We studied regulation by c-Src tyrosine kinase (Src) of KCNQ1-5 channels heterologously expressed in Chinese hamster ovary (CHO) cells and of native $\mathrm{M}$ current in rat sympathetic neurons. Using whole-cell patch clamp, we found that Src modulates currents from KCNQ3, KCNQ4, and KCNQ5 homomultimers, KCNQ2/3 heteromultimers and native M current, but not currents from KCNQ1 or KCNQ2 homomultimers. Src overexpression had two effects: a decrease of current amplitude (4- to 15-fold for cloned channels and $\sim 3$-fold for $\mathrm{M}$ current) and a slowing of activation kinetics by 2 -fold. Both Src actions were mostly reversed by bath application of the Src inhibitors erbstatin $(20 \mu \mathrm{M})$ and PP2 $(200 \mathrm{nM})$, and mimicked by the tyrosine phosphatase inhibitor sodium vanadate $(100 \mu \mathrm{M})$. Immunoprecipitation and immunoblot analysis showed Src-dependent phosphotyrosine signals associated with KCNQ3, KCNQ4, and KCNQ5 but not with KCNQ1 or KCNQ2 that may be tyrosine phosphorylation of the channel subunits. Expression of a dominant negative Src that cannot phosphorylate substrates had no effect on the current and did not induce phosphotyrosine signals associated with KCNQ3-5 subunits, further indicating that Src actions on KCNQ currents are mediated by tyrosine phosphorylation. Immunostaining and confocal analysis showed no effect of Src overexpression on the abundance of KCNQ3 protein in $\mathrm{CHO}$ cells. Finally, experiments using cloned KCNQ2/3 channels, $\operatorname{Src}$ and $\mathrm{M}_{1}$ muscarinic receptors, and sympathetic neurons demonstrated that the actions on KCNQ channels by Src and by muscarinic agonists use distinct mechanisms.

Key words: tyrosine kinase; Src; $\mathrm{K}^{+}$channel; patch-clamp; ion channel modulation; $\mathrm{M}$ current; $\mathrm{KCNQ}$ channel; signaling; muscarinic receptor

\section{Introduction}

Although identified only recently, the family of $\mathrm{KCNQ} \mathrm{K}^{+}$channels has generated great interest because of its clear physiological correlates to important $\mathrm{K}^{+}$currents in several types of tissues and its significance in human disease. The five known members of the KCNQ family, KCNQ1-5, are widely expressed in neurons, inner ear, heart, and intestine. KCNQ2, KCNQ3, and KCNQ5 underlie neuronal M currents (Wang et al., 1998; Schroeder et al., 2000; Roche et al., 2002); KCNQ1 contributes to the cardiac $I_{\mathrm{Ks}}$ current (Sanguinetti et al., 1996) and to a $\mathrm{K}^{+}$current in intestine (Warth et al., 2002), and KCNQ1 and KCNQ4 underlie $\mathrm{K}^{+}$currents in the inner ear critical to auditory function (Holt and Corey, 1999; Kubisch et al., 1999). Mutations within these KCNQ channels produce inherited syndromes of cardiac arrhythmia, epilepsy, and deafness (Wang et al., 1996; Shalaby et al., 1997; Biervert et al., 1998; Charlier et al., 1998; Singh et al., 1998; Coucke et al., 1999; Kharkovets et al., 2000). Thus, the elucidation of the mechanisms of KCNQ channel regulation is being vigorously pursued.

Although the motif of regulation of excitable cells via signaling pathways acting on ion channels has become a theme of physiology (Hille, 2001), KCNQ channels seem to be particularly strong modulatory targets. Several members of the KCNQ family are modulated by their interaction with auxiliary subunits of the KCNE family (Sanguinetti et al., 1996; Tinel et al., 2000). KCNQ1

\footnotetext{
Received June 13, 2002; revised 0ct. 15, 2002; accepted 0ct. 15, 2002.

This work was supported by a new faculty startup grant from the Howard Hughes Medical Institute, an American Heart Association (Texas Affiliate) research award, and National Institutes of Health Grant NS43394 (M.S.S.). We thank Pamela Martin and Emily McDermott for expert technical assistance.

Correspondence should be addressed to Mark S. Shapiro, Department of Physiology, University of Texas Health Science Center at San Antonio, 7703 Floyd Curl Drive, San Antonio, TX 78229. E-mail: shapirom@uthscsa.edu. Copyright $\odot 2002$ Society for Neuroscience $\quad 0270-6474 / 02 / 220084-12 \$ 15.00 / 0$
}

and KCNQ2 currents are regulated by intracellular cAMP (Yang et al., 1997; Schroeder et al., 1998). In neurons, the M current is so named for its strong modulation by muscarinic acetylcholine receptors (mAchRs; Brown and Adams, 1980; Constanti and Brown, 1981). Even after considerable study, the transduction mechanism linking $\mathrm{mAchR}$ stimulation to suppression of the $\mathrm{M}$ current is still unclear.

Intriguingly, the Src family of nonreceptor tyrosine kinases is also regulated by G-protein pathways (Igishi and Gutkind, 1998; Ma and Huang, 2002), making the synergy between G-proteinand tyrosine kinase-mediated signaling particularly interesting. The possibility that Src could play a role in KCNQ- and M-type channel regulation seemed attractive, because inhibition of $\mathrm{K}_{\mathrm{v}} 1.2$ $\mathrm{K}^{+}$channels by $\mathrm{M}_{1}$ mAchRs is mediated by tyrosine phosphorylation by Pyk2 kinase (Huang et al., 1993; Felsch et al., 1998), and Src family kinases regulate several different $\mathrm{K}^{+}$channels of the Kv1 family (Holmes et al., 1996a,b; Fadool et al., 1997; Cayabyab et al., 2000). In addition, BK-type calcium-activated (Ling et al., 2000) and HERG K ${ }^{+}$channels (Cayabyab and Schlichter, 2002) have been shown to be modulated by Src.

Here we show that three of five cloned KCNQ channels are modulated by Src kinase. We demonstrate Src effects in both a heterologous expression system using cloned channels and in primary sympathetic neurons. Our data indicate that the Srcmediated and muscarinic pathways of KCNQ channel modulation are distinct. It is suggested that modulation of KCNQ channels by Src may be important for control of neuronal excitability.

\section{Materials and Methods}

cDNA constructs. Plasmids encoding human KCNQ1, human KCNQ2, rat KCNQ3, human KCNQ4, and human KCNQ5 (GenBank accession numbers NM000218, AF110020, AF091247, AF105202, and AF249278, 
respectively) were kindly given to us by Michael Sanguinetti (University of Utah, Salt Lake City, UT; KCNQ1), David McKinnon (State University of New York, Stony Brook, NY; KCNQ2 and KCNQ3), Thomas Jentsch (Zentrum für Molekulare Neurobiologie, Hamburg, Germany; KCNQ4), and Klaus Steinmeyer (Aventis Pharma, Frankfurt am Main, Germany; KCNQ5). A plasmid containing mouse $\mathrm{M}_{1}$ receptor cDNA was given to as by Neil Nathanson (University of Washington, Seattle, $\mathrm{WA}$ ). The proto-oncogene c-Src ( $\mathrm{Src}$ ) was previously cloned from rat testis (GenBank accession number AF130457; Al-Khalili et al., 2001). K298M mutant Src (kinase-dead Src) was generated by using the Quikchange mutagenesis kit (Stratagene, La Jolla, CA) according to the instructions of the manufacturer. KCNQ1 was subcloned into pCEP4 (Invitrogen, San Diego, CA) using HindIII and XbaI. KCNQ2 and KCNQ3 were subcloned into pcDNA3 (Invitrogen) as described previously (Shapiro et al., 2000). KCNQ4 and KCNQ5 were subcloned into pcDNA3.1zeo + and pcDNA3.1zeo- (Invitrogen) using XhoI-HindIII and XbaI-EcoRI, respectively. Myc-tagged KCNQ2 -5 were generated by subcloning each channel in-frame into cytomegalovirus-myc plasmid (Clontech, Palo Alto, CA) behind the myc epitope. Rat wild-type and K298M Src were subcloned into pcDNA3.1zeo- using EcoRI.

Cell culture and transfections. Chinese hamster ovary $(\mathrm{CHO})$ cells were a kind gift of Feng Liu (Department of Pharmacology, University of Texas Health Science Center at San Antonio). Cells were grown in 100 $\mathrm{mm}$ tissue culture dishes (Falcon; Becton Dickinson, Mountain View, CA) in DMEM with $10 \%$ heat-inactivated fetal bovine serum and $0.1 \%$ penicillin and streptomycin in a humidified incubator at $37^{\circ} \mathrm{C}\left(5 \% \mathrm{CO}_{2}\right)$ and passaged every 3-4 d. Cells were discarded after $\sim 30$ passages. For transfection, cells were plated onto poly-L-lysine-coated coverslip chips and transfected $24 \mathrm{hr}$ later with Polyfect reagent (Qiagen, Hilden, Germany) according to the instructions of the manufacturer. For electrophysiological and biochemical experiments, cells were used 48-96 hr after transfection. As a marker for successfully transfected cells, cDNA encoding green fluorescent protein (GFP) was cotransfected together with the cDNAs of the genes of interest. We found that $>95 \%$ of greenfluorescing cells expressed KCNQ currents in control experiments.

Superior cervical ganglia sympathetic neuron culture and transduction. Sympathetic neurons were isolated from the superior cervical ganglia (SCG) of 2- to 6-week-old male rats (Sprague Dawley) and cultured for 2-4 d. Rats were anesthetized with halothane and decapitated. Neurons were dissociated using methods of Bernheim et al. (1991), plated on $4 \times$ $4 \mathrm{~mm}$ glass coverslips (coated with poly-L-lysine), and incubated at $37^{\circ} \mathrm{C}$ $\left(5 \% \mathrm{CO}_{2}\right)$. Fresh culture medium containing nerve growth factor $(50$ $\mathrm{ng} / \mathrm{ml}$ ) was added to the cells $3 \mathrm{hr}$ after plating. For exogenous expression of Src in SCG neurons, we used the Sindbis $\alpha$-viral expression system (Invitrogen). To construct the appropriate vectors, Src cDNA was subcloned into the multiple cloning site of pIRES2-enhanced GFP (EGFP; Clontech) using XhoI and BamHI and nonmethylated DNA extracted from SCS110 Escherichia coli, (Stratagene). The Src-IRES-EGFP coding region flanked by $X b a \mathrm{I}-\mathrm{XbaI}$ was then subcloned into the pSinRep5 vector (Invitrogen) using NheI. Proper directional cloning was verified with an XhoI digest. Pseudovirions were generated in baby hamster kidney cells according to the Sindbis expression system manual using constructed vector and $\mathrm{DH}(26 \mathrm{~S})$ helper RNAs (mMessage mMachine; Ambion). Infection of cells with these pseudovirions leads to expression of Src and EGFP as separate proteins from a common promoter, allowing us to identify transduced cells with EGFP fluorescence. Recordings from transduced cells were made between 12 and $18 \mathrm{hr}$ after exposure to pseudovirions.

Electrophysiology. The whole-cell configuration of the patch-clamp technique was used to voltage clamp and dialyze cells at room temperature $\left(22-25^{\circ} \mathrm{C}\right)$. Pipettes were pulled from borosilicate glass capillaries (1B150F-4; World Precision Instruments) using a Flaming-Brown P-97 micropipette puller (Sutter Instruments, Novato, CA) and had resistances of 2-3 $\mathrm{M} \Omega$ when filled with internal solution and measured in Ringer's solution. Membrane current was measured under whole-cell clamp with pipette and membrane capacitance cancellation, sampled at 5 msec, and filtered at $200 \mathrm{~Hz}$ by an EPC- 9 amplifier (HEKA, Lambrecht, Germany). Data acquisition and analysis were performed by Pulse software (HEKA) and ITC-16 Interface (Instrutech, Port Washington, NY).
The whole-cell access resistance was typically $5-10 \mathrm{M} \Omega$. Cells were placed in a $500 \mu \mathrm{l}$ perfusion chamber through which solution flowed at 1-2 $\mathrm{ml} / \mathrm{min}$. Inflow to the chamber was by gravity from several reservoirs, selectable by activation of solenoid valves (VaveLink 8; Automate Scientific, Inc.). Bath solution exchange was complete by $<30 \mathrm{sec}$. To observe GFP fluorescence, the polychrome IV monochromater (TILL Photonics, Martinsreid, Germany) was used in combination with an Eclipse TE300 inverted microscope (Nikon, Melville, NY).

Several voltage protocols were used to study KCNQ current in CHO cells. To evaluate the kinetics of current activation and deactivation as well as voltage dependence, $\mathrm{CHO}$ cells were held at $-60 \mathrm{mV}$, and a family of $800 \mathrm{msec}$ test voltage pulses were applied starting from -80 to $40 \mathrm{mV}$ in $10 \mathrm{mV}$ increments every $3 \mathrm{sec}$. Each test pulse was followed by a 500 $\mathrm{msec}$ step to $-60 \mathrm{mV}$, and tail currents were fit by exponential functions using PulseFit software. In experiments with oxotremorine (oxo-M) and in some erbstatin, $\mathrm{PP} 2$, and PP3 experiments, cells were held at $0 \mathrm{mV}$, and $500 \mathrm{msec}$ hyperpolarizing steps to $-60 \mathrm{mV}$, followed by $650 \mathrm{msec}$ pulses back to $0 \mathrm{mV}$, were applied every $3 \mathrm{sec}$. The amplitude of the current in $\mathrm{CHO}$ cells was usually defined as the maximal outward current at a given depolarizing potential. In some experiments, XE991 (50 $\mu \mathrm{M})$, a selective blocker of KCNQ channels, was used to verify current identity. CHO cells have negligible endogenous macroscopic $\mathrm{K}^{+}$currents under our experimental conditions, and $50 \mu \mathrm{M}$ XE991 completely blocked $\mathrm{K}^{+}$current in KCNQ-transfected CHO cells, having no effect on nontransfected ones. Cells exhibited variable "run-down" in the amplitude of KCNQ currents and usually stabilized within several minutes of whole-cell dialysis. Cells in which the rundown exceeded $3 \% / \mathrm{min}$ were discarded. In all experiments with pipette solutions containing $20 \mathrm{~mm}$ 1,2-bis(2-aminophenoxy)ethane $N, N, N^{\prime}, N^{\prime}$-tetraacetic acid (BAPTA), we waited at least 5 min after wholecell formation before starting the experiment to allow for dialysis of BAPTA and other ingredients into the cell. M currents in SCG cells were studied by holding the membrane potential at $-25 \mathrm{mV}$ and applying a $500 \mathrm{msec}$ hyperpolarizing pulse to $-60 \mathrm{mV}$ every $3 \mathrm{sec}$. The $\mathrm{M}$ current amplitude was measured at $-60 \mathrm{mV}$ from the decaying time course of deactivating current as the difference between the average of a 10 msec segment, taken 20-30 msec into the hyperpolarizing step, and the average during the last $50 \mathrm{msec}$ of that step. All results are reported as mean \pm SEM. Time constants for current activation and deactivation were calculated by fitting individual current traces by monoexponential functions using PulseFit software. Channel voltage dependence was evaluated by fitting the individual activation curves to a Boltzmann equation: $I / I_{\max }=I_{\max } /\left\{1-\exp \left[\left(V_{1 / 2}-V\right) / k\right]\right\}$, where $V_{1 / 2}$ is the voltage that produces half-maximal activation of the conductance, and $k$ is the slope factor.

Immunoprecipitations and immunoblotting. Cells were grown in 100 mm culture dishes and transfected with KCNQ1 and GFP or myc-tagged KCNQ2-5 and GFP. After $48 \mathrm{hr}$, cells were harvested with a rubber policeman in radioimmunoprecipitation assay (RIPA) lysis buffer (10 $\mathrm{mm} \mathrm{NaPO}_{4}, 150 \mathrm{~mm} \mathrm{NaCl}, 1 \% \mathrm{Na}$ deoxycholate, $1 \%$ Triton X-100, and $0.1 \%$ SDS) plus a mixture of protease ( $1 \mu \mathrm{M} \mathrm{N}-\alpha$-p-tosyl-L-lysine chloromethyl ketone, $1 \mu \mathrm{M} N$-tosyl-L-phenylalanine chloromethyl ketone, 1 $\mu \mathrm{M}$ 4-(2-aminoethyl)-benzene sulfonylfluoride $\mathrm{HCl}, 1 \mu \mathrm{M} \mathrm{E}-64,1 \mu \mathrm{g} / \mathrm{ml}$ leupeptin, and $1 \mu \mathrm{M}$ pepstatin; all from Sigma, St. Louis, MO) and tyrosine phosphatase (in $\mu \mathrm{M}: 100 \mathrm{ZnCl}_{2}, 100 \mathrm{Na}_{2} \mathrm{MoO}_{4}, 500 \mathrm{NaF}, 100 \mathrm{Na}$ pyrophosphate, and $40 \mathrm{Na}_{3} \mathrm{VO}_{4}$; all from Sigma) inhibitors, and lysate proteins were quantified with a BCA assay (Pierce, Rockford, IL). Proteins ( $400 \mu \mathrm{g} /$ reaction) were immunoprecipitated overnight at $4^{\circ} \mathrm{C}$ using $2 \mu \mathrm{g}$ of anti-phosphotyrosine antibodies (Upstate Biotechnology, Lake Placid, NY) and $40 \mu$ l of protein A/G beads (Santa Cruz Biotechnology, Santa Cruz, CA). Immunoprecipitated proteins bound to pelleted protein $A / G$ beads were washed thoroughly in RIPA buffer, denatured in Laemmli sample buffer, separated using SDS-PAGE, and electroblotted onto nitrocellulose membranes. Immunoblots were probed with mouse anti-myc (KCNQ2-5; Clontech) or anti-KCNQ1 (Santa Cruz Biotechnology) primary antibodies (1:1000 dilution, overnight at $\left.4^{\circ} \mathrm{C}\right)$ in a blocking solution containing 5\% nonfat dry milk (Carnation) in TBS and Tween 20 and subsequently treated with goat anti-mouse horseradish peroxidase-conjugated secondary antibodies (1:25,000 dilution, $45 \mathrm{~min}$, room temperature; Jackson ImmunoResearch, West Grove, PA). Blots 
were developed with enhanced chemiluminescence (Supersignal; Pierce) and exposed on $\mathrm{x}$-ray film (Biomax).

Immunostaining and confocal analysis. Cells were transfected with myc-tagged KCNQ3 and GFP or myc-tagged KCNQ3, Src, and GFP, grown on poly-L-lysine-coated coverslips, fixed in $4 \%$ paraformaldehyde, washed twice with $100 \mathrm{~mm}$ sodium phosphate buffer (PB), $\mathrm{pH} 7.4$, and three times with PBS, and blocked with $5 \%$ goat serum and $0.1 \%$ saponin in PBS (PBS + GS). The cells were incubated for $3 \mathrm{hr}$ at room temperature with primary anti-myc antibody (Clontech) diluted 1:1000 in PBS+GS. Cells were washed six times with PBS and then incubated with goat rhodamine red-conjugated anti-mouse secondary antibody (1:150; Jackson ImmunoResearch) in PBS + GS for $1 \mathrm{hr}$. Cells were then washed three times with PBS, twice with $\mathrm{PB}$, and three times with water. Air-dried slides were mounted on a drop of Vectashield (Vector Laboratories, Burlingame, CA) and sealed with nail polish. Stained cells were viewed with an Olympus Optical (Tokyo, Japan) FV-500 confocal microscope in the Optical Imaging Core Facility at the University of Texas Health Science Center using the lasers and excitation and emission filters appropriate for GFP and rhodamine red. Because GFP was used as a reporter for successful transfection, images were collected in "sequential" mode to avoid bleed-through of the GFP (green) and rhodamine (red) signals. Single images were collected 3-5 $\mu \mathrm{m}$ above the surface of the coverslip. The fluorescence intensity was quantified using TotalLab software (Nonlinear Dynamics, Newcastle, UK).

Solutions and materials. The external solution used to record KCNQ currents in CHO cells contained (in $\mathrm{mM}$ ): $160 \mathrm{NaCl}, 2.5 \mathrm{KCl}, 2 \mathrm{CaCl}_{2}, 1$ $\mathrm{MgCl}_{2}$, and $10 \mathrm{HEPES}, \mathrm{pH} 7.4$ with $\mathrm{NaOH}$. The regular pipette solution contained (in mM): $160 \mathrm{KCl}, 5 \mathrm{MgCl}_{2}, 5$ HEPES, 0.1 BAPTA, $3 \mathrm{~K}_{2} \mathrm{ATP}$, and 0.1 NaGTP, pH 7.4 with KOH. In oxotremorine experiments, a $\mathrm{Ca}^{2+}$-clamping mixture was used, which contained (in mM): 20 BAPTA, $10 \mathrm{CaCl}_{2}, 110 \mathrm{KCl}, 5 \mathrm{MgCl}_{2}, 5 \mathrm{HEPES}, 3 \mathrm{~K}_{2} \mathrm{ATP}$, and $0.1 \mathrm{NaGTP}$ and 100 $\mu \mathrm{g} / \mathrm{ml}$ pentosan polysulfate, $\mathrm{pH} 7.4$ with $\mathrm{KOH}$. Reagents were obtained as follows: oxotremorine methiodide, Research Biochemicals (Natick, MA); BAPTA, Molecular Probes (Eugene, OR); DMEM, fetal bovine serum, nerve growth factor, penicillin, and streptomycin, Invitrogen; ATP, GTP, pentosan polysulfate, and sodium orthovanadate, Sigma; erbstatin, PP2, and PP3 (Calbiochem); and XE991, a kind gift from Michael E. Schnee (DuPont Pharmaceuticals, Billerica, MA).

\section{Results}

c-Src suppresses current amplitudes and slows activation of cloned KCNQ2/3 heteromultimers

We first studied the effect of rat c-Src (Src) on cloned KCNQ2/3 $\mathrm{K}^{+}$channels using a heterologous expression system. CHO cells were cotransfected with cDNA coding for KCNQ2 and KCNQ3 subunits with or without the cDNA for Src. Previous work has shown that coexpression of KCNQ2 and KCNQ3 recapitulates heteromeric KCNQ2/3 channels with the biophysical, pharmacological, and modulatory properties of the M current of sympathetic neurons (Wang et al., 1998; Selyanko et al., 2000; Shapiro et al., 2000). We used coexpression of GFP as a reporter for successful transfection, and only cells that fluoresced green were chosen for study using whole-cell clamp. CHO cells transfected with KCNQ2 and KCNQ3 expressed voltage-gated $\mathrm{K}^{+}$currents with slow activation kinetics typical of KCNQ channels (Fig. 1A), whereas nontransfected $\mathrm{CHO}$ cells had negligible macroscopic $\mathrm{K}^{+}$currents (data not shown).

We compared the properties of KCNQ2/3 currents in cells only transfected with the channels to cells also transfected with Src. Immunoblot analysis showed that Src-transfected CHO cells highly express Src protein and that non-Src-transfected cells contain a modest level of endogenous Src (data not shown). Src cotransfection had two main actions: (1) a strong suppression of current amplitudes and (2) a slowing of activation kinetics. Shown in Figure $1 \mathrm{~A}$ are families of currents from a cell without (left) and with (right) Src cotransfection. The Src-transfected cell
A

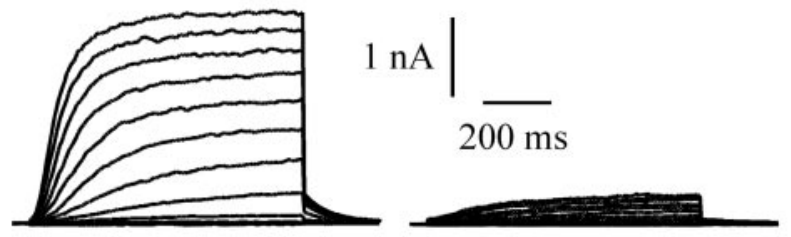

B

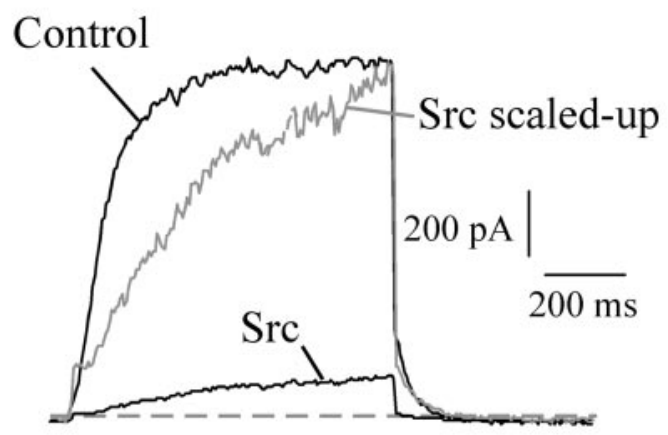

C

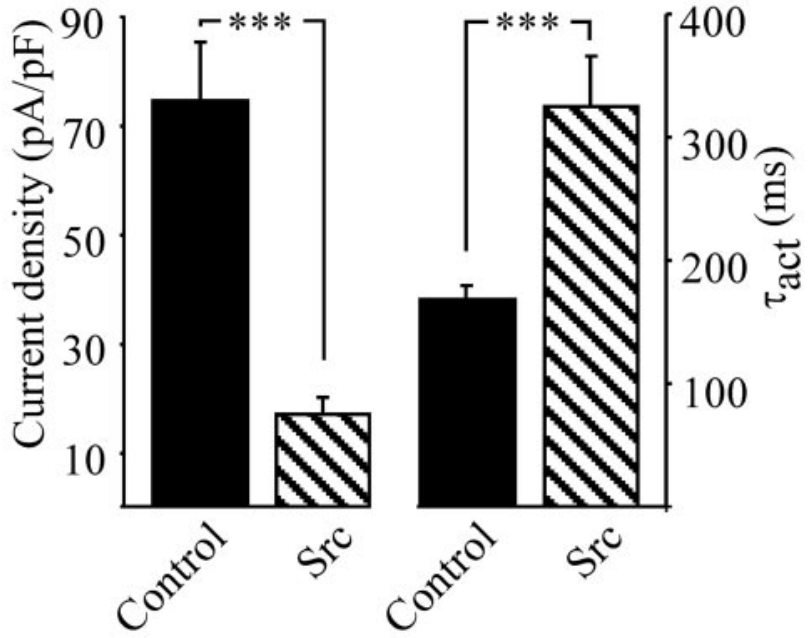

Figure 1. Src suppresses the amplitude and slows activation of currents from KCNQ2/3 heteromultimers expressed in $\mathrm{CHO}$ cells. $A$, Superimposed current traces recorded from a cell cotransfected with KCNQ2 and KCNQ3 (Control) or a cell cotransfected with KCNQ2, KCNQ3, and rat c-Src (Src). Currents were evoked by a family of $500 \mathrm{msec}$ voltage pulses from -80 to $40 \mathrm{mV}$ in $10 \mathrm{mV}$ increments from a holding potential of $-60 \mathrm{mV}$. B, Superimposed current traces at $0 \mathrm{mV}$ from the current families similar to those shown in $A$, shown at an expanded scale. The trace from the cell cotransfected with Src is also shown scaled up ( gray) to match the control trace to more clearly show the effect of Src on activation kinetics. C, Summarized data for the current density (left) and activation $\tau_{\text {act }}$ (right) for the currents recorded at $0 \mathrm{mV}$ (as in B), from control $(n=45)$ and Src cotransfected $(n=42)$ cells. ${ }^{*} p \leq 0.05 ;{ }^{* *} p \leq 0.01 ;{ }^{* * *} p \leq 0.001$ in this and subsequent figures.

displayed profoundly reduced KCNQ2/3 current amplitudes at all voltages tested, relative to the control cell. Figure $1 B$ shows that Src overexpression also slowed activation kinetics. Shown are current traces evoked by $800 \mathrm{msec}$ voltage pulse from -60 to 
Table 1. Effect of Src on the biophysical properties of KCNQ channels

\begin{tabular}{|c|c|c|c|c|c|}
\hline \multirow[b]{2}{*}{ Transfection } & \multicolumn{2}{|c|}{ Current density (pA/pF) } & \multicolumn{2}{|c|}{ Activation $\tau$ (msec) } & \multirow{2}{*}{$\begin{array}{l}\text { Deactivation } \tau \text { (msec) } \\
(-60 \mathrm{mV})\end{array}$} \\
\hline & $0 \mathrm{mV}$ & $40 \mathrm{mV}$ & $0 \mathrm{mV}$ & $40 \mathrm{mV}$ & \\
\hline KCNQ1 & $\begin{array}{l}11.8 \pm 2.6 \\
(n=17)\end{array}$ & $\begin{array}{l}19.2 \pm 4.2 \\
(n=17)\end{array}$ & $\begin{array}{l}210 \pm 20 \\
(n=17)\end{array}$ & $\begin{array}{l}90.9 \pm 15.8 \\
(n=17)\end{array}$ & $\begin{array}{l}455 \pm 87 \\
(n=7)\end{array}$ \\
\hline $\mathrm{KCNQ1}+\mathrm{SrC}$ & $\begin{array}{l}12.7 \pm 5.5 \\
(n=13)\end{array}$ & $\begin{array}{l}22.1 \pm 6.0 \\
(n=13)\end{array}$ & $\begin{array}{l}199 \pm 22 \\
(n=13)\end{array}$ & $\begin{array}{l}90.1 \pm 21.4 \\
(n=13)\end{array}$ & $\begin{array}{l}366 \pm 68 \\
(n=8)\end{array}$ \\
\hline KCNQ2 & $\begin{array}{l}7.85 \pm 2.19 \\
(n=7)\end{array}$ & $\begin{array}{l}8.84 \pm 2.72 \\
(n=7)\end{array}$ & $\begin{array}{l}209 \pm 19 \\
(n=7)\end{array}$ & $\begin{array}{l}129 \pm 20 \\
(n=7)\end{array}$ & $\begin{array}{l}153 \pm 22 \\
(n=5)\end{array}$ \\
\hline $\mathrm{KCNQ2}+\mathrm{SrC}$ & $\begin{array}{l}5.65 \pm 1.53 \\
(n=8)\end{array}$ & $\begin{array}{l}8.49 \pm 2.20 \\
(n=8)\end{array}$ & $\begin{array}{l}223 \pm 24 \\
(n=8)\end{array}$ & $\begin{array}{l}127 \pm 9 \\
(n=8)\end{array}$ & $\begin{array}{l}118 \pm 28 \\
(n=5)\end{array}$ \\
\hline KCNQ3 & $\begin{array}{l}13.0 \pm 3.6 \\
(n=8)\end{array}$ & $\begin{array}{l}15.7 \pm 3.1 \\
(n=8)\end{array}$ & $\begin{array}{l}149 \pm 16 \\
(n=8)\end{array}$ & $\begin{array}{l}64.4 \pm 5.6 \\
(n=8)\end{array}$ & $\begin{array}{l}95.4 \pm 8.8 \\
(n=3)\end{array}$ \\
\hline $\mathrm{KCNQ3}+\mathrm{SrC}$ & $\begin{array}{l}0.85 \pm 0.27^{* *} \\
(n=6)\end{array}$ & $\begin{array}{l}2.13 \pm 0.84^{* *} \\
(n=6)\end{array}$ & $\begin{array}{l}289 \pm 43^{* *} \\
(n=5)\end{array}$ & $\begin{array}{l}220 \pm 57^{* *} \\
(n=6)\end{array}$ & ND \\
\hline $\mathrm{KCNQ2/3}$ & $\begin{array}{l}74.5 \pm 10.8 \\
(n=45)\end{array}$ & $\begin{array}{l}127 \pm 19 \\
(n=26)\end{array}$ & $\begin{array}{l}169 \pm 10 \\
(n=45)\end{array}$ & $\begin{array}{l}103 \pm 5 \\
(n=26)\end{array}$ & $\begin{array}{l}74.5 \pm 6.0 \\
(n=29)\end{array}$ \\
\hline $\mathrm{KCNQ2/3}+\mathrm{SrC}$ & $\begin{array}{l}17.2 \pm 2.6^{* * *} \\
(n=42)\end{array}$ & $\begin{array}{l}32.2 \pm 5.5^{* * *} \\
(n=41)\end{array}$ & $\begin{array}{l}326 \pm 39^{* * *} \\
(n=42)\end{array}$ & $\begin{array}{l}165 \pm 11^{* * * *} \\
(n=41)\end{array}$ & $\begin{array}{l}52.9 \pm 4.8^{*} \\
(n=16)\end{array}$ \\
\hline KCNQ2/3 + K298M Src & $\begin{array}{l}50.6 \pm 8.8 \\
(n=8)\end{array}$ & $\begin{array}{l}79.0 \pm 13.3 \\
(n=8)\end{array}$ & $\begin{array}{l}141 \pm 19 \\
(n=8)\end{array}$ & $\begin{array}{l}92.6 \pm 9.2 \\
(n=8)\end{array}$ & $\begin{array}{l}63.5 \pm 5.4 \\
(n=8)\end{array}$ \\
\hline KCNQ4 & $\begin{array}{l}115 \pm 25 \\
(n=6)\end{array}$ & $\begin{array}{l}182 \pm 47 \\
(n=6)\end{array}$ & $\begin{array}{l}179 \pm 42 \\
(n=5)\end{array}$ & $\begin{array}{l}163 \pm 39 \\
(n=5)\end{array}$ & $\begin{array}{l}103 \pm 17 \\
(n=6)\end{array}$ \\
\hline KCNQ4 + SrC & $\begin{array}{l}28.3 \pm 8.7^{* *} \\
(n=6)\end{array}$ & $\begin{array}{l}61.1 \pm 18.7^{*} \\
(n=6)\end{array}$ & $\begin{array}{l}412 \pm 95^{*} \\
(n=6)\end{array}$ & $\begin{array}{l}454 \pm 93^{*} \\
(n=6)\end{array}$ & $\begin{array}{l}98 \pm 11 \\
(n=5)\end{array}$ \\
\hline KCNQ5 & $\begin{array}{l}18.9 \pm 3.9 \\
(n=8)\end{array}$ & $\begin{array}{l}33.6 \pm 8.5 \\
(n=8)\end{array}$ & $\begin{array}{l}162 \pm 25 \\
(n=8)\end{array}$ & $\begin{array}{l}150 \pm 28 \\
(n=8)\end{array}$ & $\begin{array}{l}125 \pm 26 \\
(n=6)\end{array}$ \\
\hline KCNQ5 + SrC & $\begin{array}{l}3.44 \pm 0.78^{* *} \\
(n=7)\end{array}$ & $\begin{array}{l}7.74 \pm 2.00^{*} \\
(n=7)\end{array}$ & $\begin{array}{l}348 \pm 33^{* * *} \\
(n=7)\end{array}$ & $\begin{array}{l}334 \pm 56^{* *} \\
(n=7)\end{array}$ & ND \\
\hline
\end{tabular}

ND, Not determined.

${ }^{*} p \leq 0.05 ;{ }^{* *} p \leq 0.01 ;{ }^{* * *} p \leq 0.001$.

$0 \mathrm{mV}$. The current trace from the Src-transfected cell is also shown scaled up to match the trace from the control cell, clearly showing that the activation kinetics in this cell are slower than in control. Src overexpression also induced modest acceleration of current deactivation (estimated using tail currents similar to that shown in Fig. $1 B)$. Such data are summarized in Figure $1 C$ and Table 1. Coexpression of Src with KCNQ2/3 resulted in a 4.5-fold reduction of current density and a 2-fold slowing of activation kinetics at $0 \mathrm{mV}$.

\section{c-Src actions are reversed by tyrosine kinase inhibitors and mimicked by a tyrosine phosphatase inhibitor}

To investigate the mechanism by which Src acts on KCNQ2/3 channels, we first asked whether pharmacological inhibitors of tyrosine kinases could acutely reverse Src actions. The broadspectrum tyrosine kinase inhibitor erbstatin and the Src familyspecific inhibitor PP2 were used in patch-clamp experiments on $\mathrm{CHO}$ cells expressing KCNQ2/3 channels together with Src (Fig. $2 A-C)$. Families of KCNQ2/3 currents were obtained before and $15 \mathrm{~min}$ after addition of drugs to the bathing solution. Application of $20 \mu \mathrm{M}$ erbstatin to the bath increased current amplitudes and accelerated activation kinetics from a $\mathrm{CHO}$ cell transfected with KCNQ2/3 and Src (Fig. $2 A$ ). The effect reached its maximum within 15 min of erbstatin application. Figure $2 B$ shows experiments in which the specific Src inhibitor PP2 or its inactive analog PP3 (both at $200 \mathrm{~nm}$ ) were used. In 5 of 6 experiments, PP2, similar to erbstatin, increased current amplitude and accelerated activation kinetics. In contrast, application of PP3 had no effect $(n=6)$. These data are summarized in Figure 2C. Erbstatin increased current amplitudes at $0 \mathrm{mV}$ by $2.3 \pm 0.2$-fold $(p \leq 0.002 ; n=7)$ and the activation time constants $\left(\tau_{\text {act }}\right)$ at $0 \mathrm{mV}$ were decreased to $46.6 \pm$ $4.9 \%(p \leq 0.001 ; n=7)$ of their initial values.

To test the effect of Src inhibitors on KCNQ2/3 currents in cells not overexpressing $\mathrm{Src}$, we repeated the experiments shown in Figure $2 \mathrm{~A}-\mathrm{C}$ in non-Src-overexpressing $\mathrm{CHO}$ cells. We found that both erbstatin and PP2 induced small but reliable "run-up" of the KCNQ2/3 current within 10-15 min of perfusion with erbstatin (15 $\pm 7 \%$, four of five cells) or PP2 (13 $\pm 6 \%$, four of five cells; $p \leq 0.05$; paired Student's $t$ test), a time course similar to that found in experiments with Src-overexpressing cells. One such experiment is shown in Figure 2D. However, PP3 did not increase the current $(n=3)$. These data are consistent with modest endogenous Src-like activity in CHO cells.

Phosphorylation states represent a balance between the activities of protein kinases and phosphatases. Indeed, we expect that the effects of Src in CHO cells shown in Figure 1 are attributable to tonic Src activity that is greatly augmented by overexpressing Src, resulting in the balance between phosphorylation and dephosphorylation being biased toward the former. Thus, we tested whether the effects of Src overexpression would be mimicked by treatment of non-Src-overexpressing cells with sodium vanadate, an inhibitor of protein tyrosine phosphatases (Fig. 3). We first compared $\mathrm{CHO}$ cells transfected with $\mathrm{KCNQ} 2 / 3$, but not Src, which had or had not been preincubated with vanadate $(100 \mu \mathrm{M})$ in the culture medium for $1 \mathrm{hr}$. Figure $3, A$ and $B$, shows representative experiments. In the vanadate-treated cell, the current amplitude was profoundly suppressed, and activation kinetics was slowed, mimicking the effect of Src overexpression. Such data are summarized in Figure $3 C$. Measured at $0 \mathrm{mV}$, the current density and $\tau_{\text {act }}$ in control cells (measured during the same days as the vanadate experiments) were $89.9 \pm 27.8 \mathrm{pA} / \mathrm{pF}(n=9)$ and $195 \pm 17 \mathrm{msec}(n=9)$, respectively, but in vanadate-treated cells they were $16.8 \pm 5.1 \mathrm{pA} / \mathrm{pF}(n=9 ; p \leq 0.01)$ and $418 \pm 55 \mathrm{msec}$ $(n=9 ; p \leq 0.001)$.

The decrease of KCNQ2/3 current density and slowing of the current activation in Src-cotransfected cells was accompanied by a shift of channel voltage dependence toward more depolarizing 
A
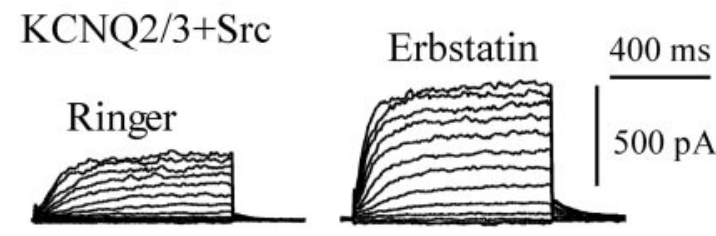

B

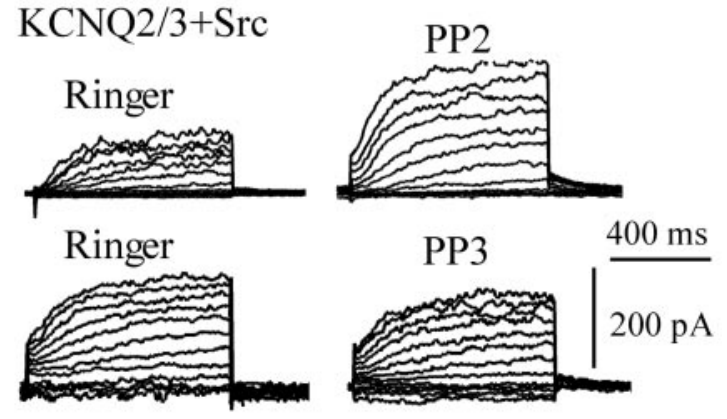

C
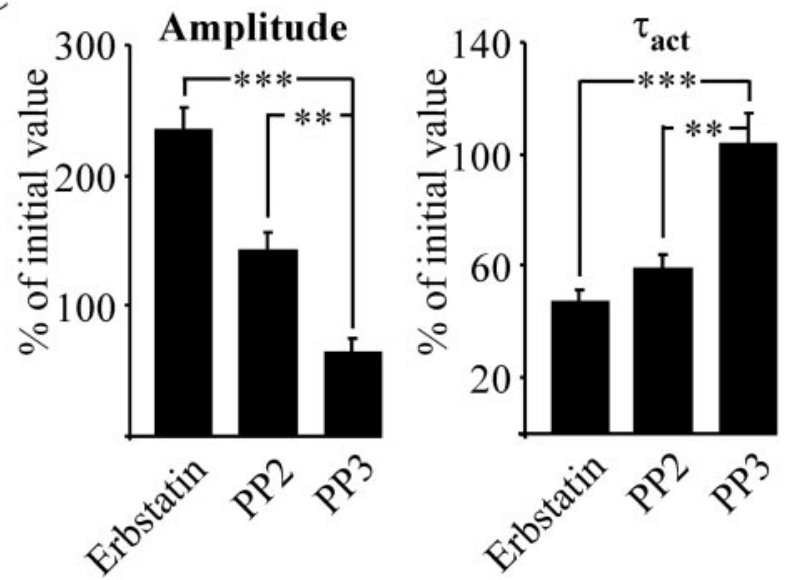

D

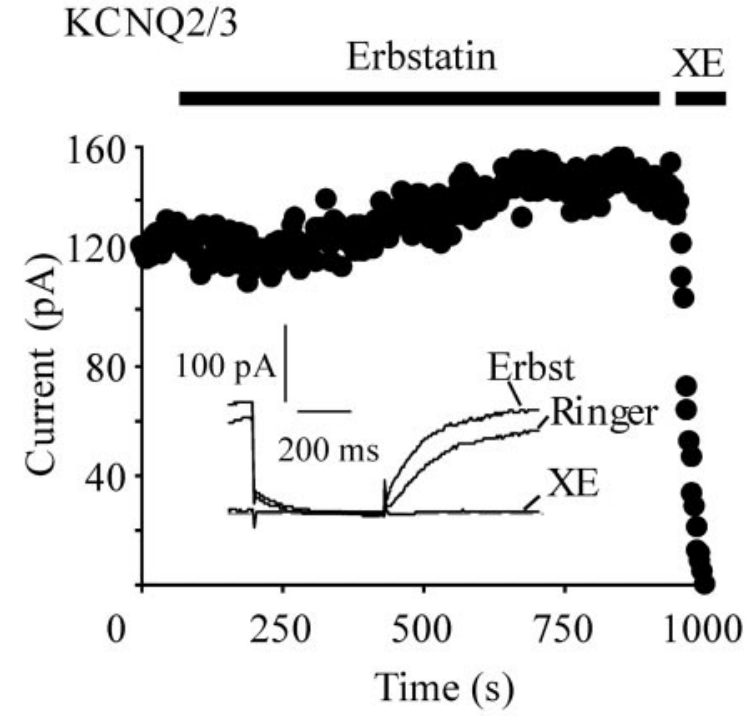

Figure 2. Src inhibitors reverse Src effects on $\mathrm{KCNQ} 2 / 3$ currents. $A$, Currents recorded from a cell cotransfected with KCNQ2, KCNQ3, and Src as in Figure 1 before and after (15 min) erbstatin application. $B$, Experiment similar to that in $A$, but the specific Src inhibitor PP2 (200 nm; top panel) or its inactive analog, PP3 (200 nм; bottom panel) was applied instead of erbstatin. C, Summary of the erbstatin, PP2, and PP3 actions on current amplitude (left) and $\tau_{\text {act }}$ (right), expressed as a percentage of the initial values (before inhibitor application). D, Current ampli- potentials (Fig. 4A). We estimated the voltage dependence of activation of KCNQ2/3 heteromultimers using tail current amplitudes recorded at $-60 \mathrm{mV}$ after a family of prepulses from -80 to $40 \mathrm{mV}$. The half-maximal voltages of current activation $\left(\mathrm{V}_{1 / 2}\right)$ in cells transfected with KCNQ2/3 alone and those transfected with KCNQ2/3 together with Src were $-21.1 \pm 1.5 \mathrm{mV}(n=19)$ and $-11.8 \pm 2.6 \mathrm{mV}(p \leq 0.01 ; n=19)$ respectively. Erbstatin completely reversed this effect (Fig. $4 B$ ). The $\mathrm{V}_{1 / 2}$ of KCNQ2/3 channels in Src-transfected cells after erbstatin application was $-23.6 \pm 4.9 \mathrm{mV}(p \leq 0.05 ; n=5)$. In contrast, vanadate treatment mimicked the effect of Src on the $\mathrm{V}_{1 / 2}$ of current activation (Fig. 4C), shifting the $\mathrm{V}_{1 / 2}$ of cells transfected with KCNQ2/3 channels (but not Src) to $-8.0 \pm 3.8 \mathrm{mV}(p \leq 0.001 ; n=6)$. Because the voltage dependence of the activation of the conductance of voltage-gated channels is the sum effect of the rates of activation and deactivation, the shift of the voltage dependence induced by Src is biophysically consistent with (and expected from) a slowing of $\tau_{\text {act }}$. It should be pointed out that the effect of Src on current amplitude (greater than fourfold for KCNQ2/3 heteromultimers) is much more profound than would be expected from just a $10 \mathrm{mV}$ shift in voltage dependence.

\section{c-Src suppresses the M current in SCG neurons}

We then tested whether Src overexpression in rat sympathetic neurons would have an effect on endogenous $M$ current similar to that on currents from cloned KCNQ2/3 channels. Dissociated neurons from rat SCG were cultured overnight and exogenously expressed with Src and EGFP or just EGFP as a control, using the Sindbis $\alpha$-viral expression system (see Materials and Methods). Figure $5 \mathrm{~A}$ shows transmitted light (left) and fluorescent (right; $\lambda_{\text {exit }}=470 \mathrm{~nm}$ ) micrographs of a successfully transduced SCG cell. We compared the M current density in Src-transduced and control neurons, quantified as the amplitude per picofarad of the time-dependent deactivating current at $-60 \mathrm{mV}$, using a classical $\mathrm{M}$ current voltage protocol. Figure $5 B$ shows $M$ current traces from a cell transduced with Src and EGFP or only EGFP (Control). The M current amplitude in the Src-transduced neuron is much smaller than in the control neuron. Such data are summarized in Figure $5 B$ (right). The $\mathrm{M}$ current density was reduced from $1.8 \pm 0.1 \mathrm{pA} / \mathrm{pF}(n=7)$ in cells expressing EGFP alone to $0.6 \pm 0.2 \mathrm{pA} / \mathrm{pF}(p \leq 0.001 ; n=8)$ in cells expressing EGFP together with Src. Thus, Src suppresses native M currents in neurons as well as from heterologously expressed KCNQ2/3 channels. Although we qualitatively observed slowing of $\mathrm{M}$ current activation kinetics by Src overexpression, we could not quantify this effect because of interference from other endogenous SCG $\mathrm{K}^{+}$currents.

We then investigated the effect of vanadate on the M current in nontransduced neurons. Similar to KCNQ2/3 currents in $\mathrm{CHO}$ cells, pretreatment of SCG cells with $100 \mu \mathrm{M}$ vanadate for 1 hr suppressed the M current density (Fig. 5C). The effect is summarized in Figure $5 C$ (right). M-current density was reduced from $0.9 \pm 0.1 \mathrm{pA} / \mathrm{pF}(n=15)$ in control cells to $0.4 \pm 0.1 \mathrm{pA} / \mathrm{pF}$ in vanadate-treated cells ( $p \leq 0.05 ; n=13$ ). Thus, for both cloned KCNQ2/3 heteromultimers in $\mathrm{CHO}$ cells and native $\mathrm{M}$

$\leftarrow$

tudes at $0 \mathrm{mV}$ during voltage pulses given every 3 sec consisting of a 500 msec step to $-60 \mathrm{mV}$, followed by a 650 msec step back to the holding potential of $0 \mathrm{mV}$, in a cell cotransfected with KCNQ2 and KCNQ3 but not Src. Erbstatin and XE991 $(50 \mu \mathrm{m})$ were applied during the times indicated by the bars. Inset, Currents at the indicated times during the experiment. The dotted line indicates the zero current level. 
A $\mathrm{KCNQ} 2 / 3$

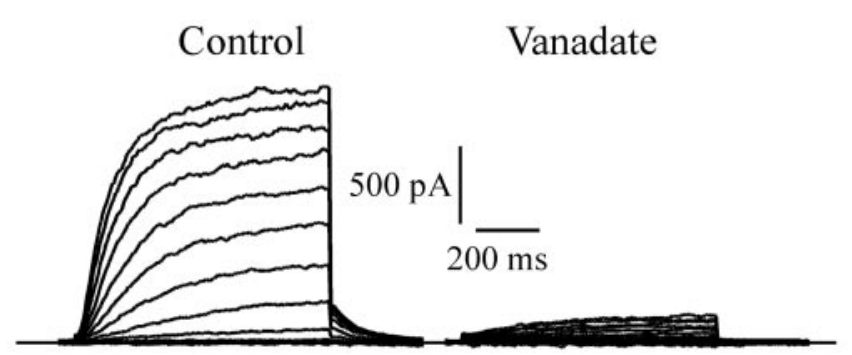

B

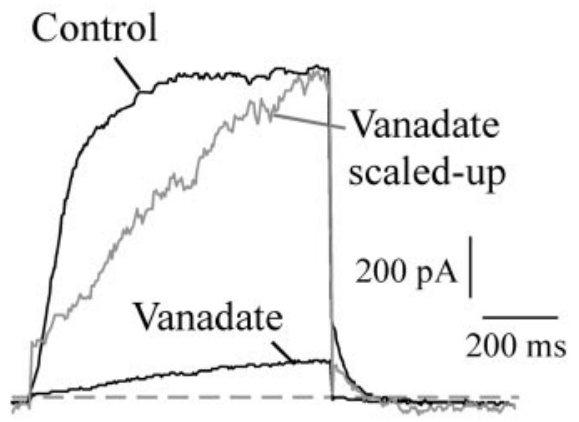

C

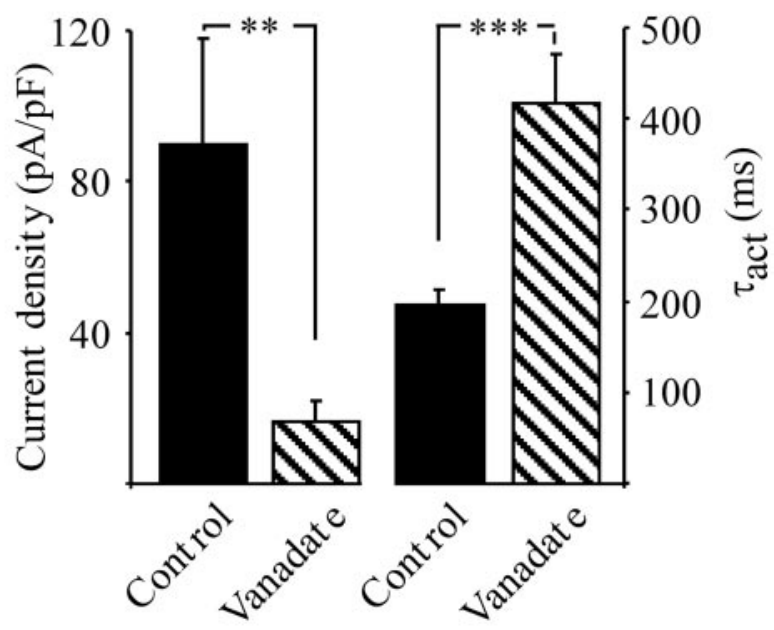

Figure 3. A tyrosine phosphatase inhibitor mimics Src actions. A, Current traces recorded from a cell cotransfected with KCNQ2 and KCNQ3 (Control) and from a similar cell preincubated for $1 \mathrm{hr}$ with $100 \mu \mathrm{m}$ sodium vanadate (Vanadate). Currents were recorded as in Figure 1A. B, Superimposed currents at $0 \mathrm{mV}$ similar to that shown in $A$ are shown at an expanded scale. The trace from the cell incubated in Vanadate is also shown scaled up ( gray) to match the Control trace to more clearly show the effect of vanadate treatment on activation kinetics. C, Summarized data for the current density (left) and $\tau_{\text {act }}$ (right) for the currents recorded at $0 \mathrm{mV}$ (as in $B$ ) from control $(n=9)$ and vanadate-treated $(n=9)$ cells.

current in SCG neurons, blockade of tyrosine phosphatases mimics Src overexpression, suggesting that Src acts by phosphorylating target proteins.

A kinase-dead c-Src is without effect

To further test whether the effects of Src are dependent on phosphorylation, we compared the effect of overexpression of wild-
A

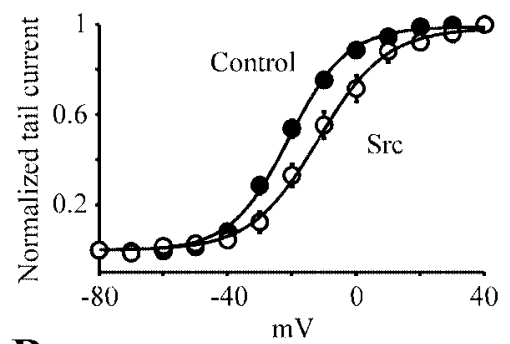

B
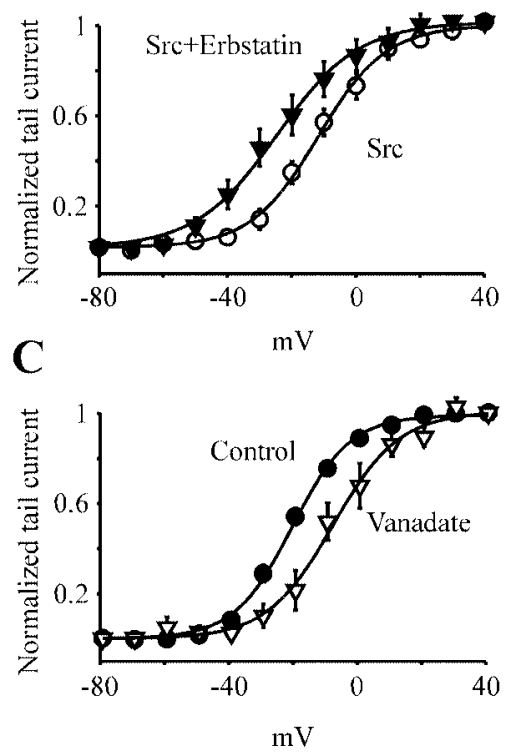

Figure 4. Src overexpression shifts the voltage dependence of KCNQ2/3 currents. Shown are activation curves generated from normalized tail currents $\left(I / I_{\max }\right)$ recorded by $500 \mathrm{msec}$ voltage steps to $-60 \mathrm{mV}$ after a family of test potentials from -80 to $40 \mathrm{mV}$ in $10 \mathrm{mV}$ increments. $A$, Activation curves for cells transfected with KCNQ2 and KCNQ3 only (Control, filled circles; $n=19$ ) or for those also cotransfected with Src (Src, open circles; $n=19$ ). B, Activation curves for cells transfected with KCNQ2, KCNQ3, and Src before (Src, open circles; $n=19$ ) and 15 min after application of $20 \mu \mathrm{m}$ erbstatin (Src + Erbstatin, filled triangles; $n=5$ ). C, Activation curves for cells transfected with KCNQ2 and KCNQ3 either without (Control, filled circles; $n=19$ ) or after 1 hr preincubation with $100 \mu \mathrm{m}$ sodium vanadate (Vanadate, open triangles; $n=6$ ). The curves shown in $A-C$ were fit to Boltzmann equations (see Materials and Methods), and the parameters for each fit are stated in the text.

type Src on KCNQ2/3 heteromultimers with that of a kinasedead mutant Src that has a point mutation in the ATP binding site (K298M), which completely abolishes kinase activity (Miller et al., 2000). The results of these experiments are shown in Figure 6. Immunoblots with an anti-Src antibody showed similar levels of expression of wild-type and K298M Src (Fig. 6, inset). Cotransfection of K298M Src had little effect on current amplitudes or on activation kinetics of the KCNQ2/3 current (Fig. 6A,B). The current density and $\tau_{\text {act }}$ at $0 \mathrm{mV}$ in cells cotransfected with KCNQ2/3 and K298M Src were $50.6 \pm 8.8 \mathrm{pA} / \mathrm{pF}(n=8)$ and $141 \pm 18 \mathrm{msec}$ $(n=8)$. In control cells transfected only with KCNQ2/3 (same days as when experiments with K298M Src were performed), the current density and $\tau_{\text {act }}$ at $0 \mathrm{mV}$ were $61.1 \pm 18.7 \mathrm{pA} / \mathrm{pF}(n=8)$ and $140 \pm 12 \mathrm{msec}(n=8)$. These values in both control and K298M Src-cotransfected cells were also not significantly different from the pooled values of control cells (Student's $t$ test; $p \leq$ 0.05 ; Table 1 ). 
A
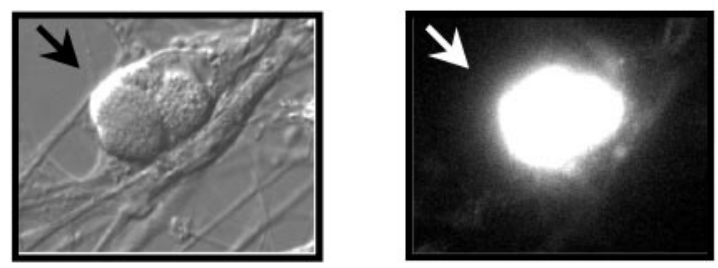

B
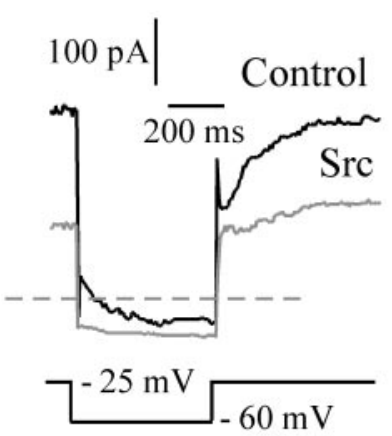

C

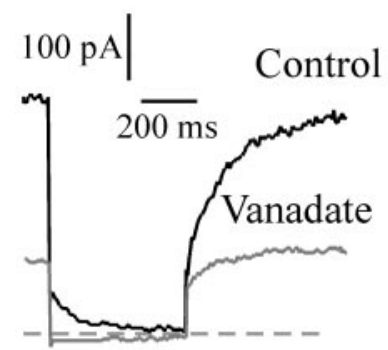

A

KCNQ2/3

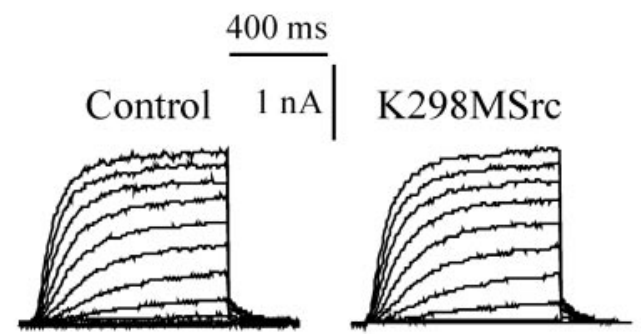

IB: Src
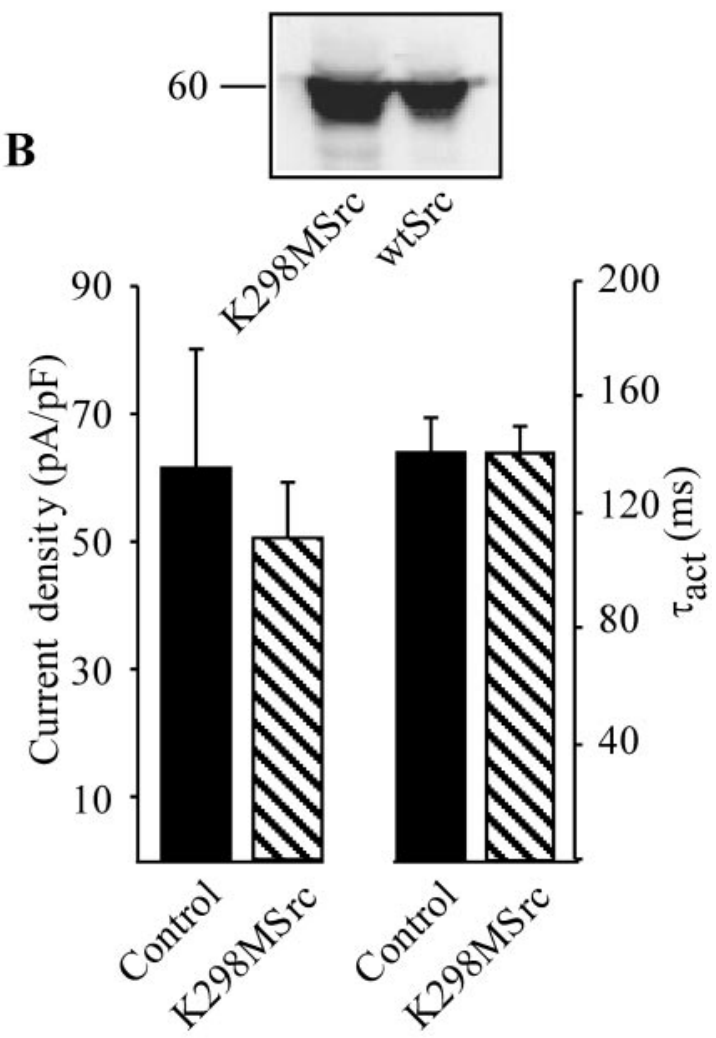

Figure 6. A kinase-dead mutant Src does not affect the KCNQ2/3 current. $A$, Currents recorded from a cell transfected with KCNQ2 and KCNQ3 alone (left, Control) or together with kinase-dead (K298M) Src (right, K298MSrc). Currents were recorded as in Figure 1A. Inset, Immunoblots from lysates of cells transfected with wild-type or K298M Src. Lysate proteins were separated by SDS-PAGE and transferred to nitrocellulose, and the immunoblot was probed with anti-Src antibodies. C, Summarized data of the current density (left) and $\tau_{\text {act }}$ (right) at $0 \mathrm{mV}$ for control $(n=8)$ and K298M Src-cotransfected (hatched columns; $n=7)$ cells.

marized in Table 1 and Figure 7. Cotransfection of Src with KCNQ1 or KCNQ2 had no effect on the current density or on activation kinetics of the currents. In contrast, current amplitudes from KCNQ3, KCNQ4, and KCNQ5 homomultimers were dramatically reduced by Src cotransfection (Fig. 7A, $B$, Table 1). The largest effect of Src was observed for KCNQ3, for which the current density at $0 \mathrm{mV}$ was 15 times lower in Src-overexpressing cells compared with cells expressing KCNQ3 alone. The activation time constants of KCNQ3 currents were also twofold larger in Src-cotransfected cells. In cells transfected with KCNQ4 or KCNQ5, cotransfection of Src decreased the current density at 0 $\mathrm{mV}$ by 4.0 - and 5.5 -fold and increased $\tau_{\text {act }}$ by 2.3 - and 2.1 -fold,

\begin{abstract}
respectively. These data are summarized in Figure $7 B$ and Table 1.
\end{abstract}
We investigated the sensitivity of the five different KCNQ channels to modulation by Src. All five cloned channels of the KCNQ family (KCNQ1-5) were individually expressed in $\mathrm{CHO}$ cells with or without Src. The data from these experiments are sum- 

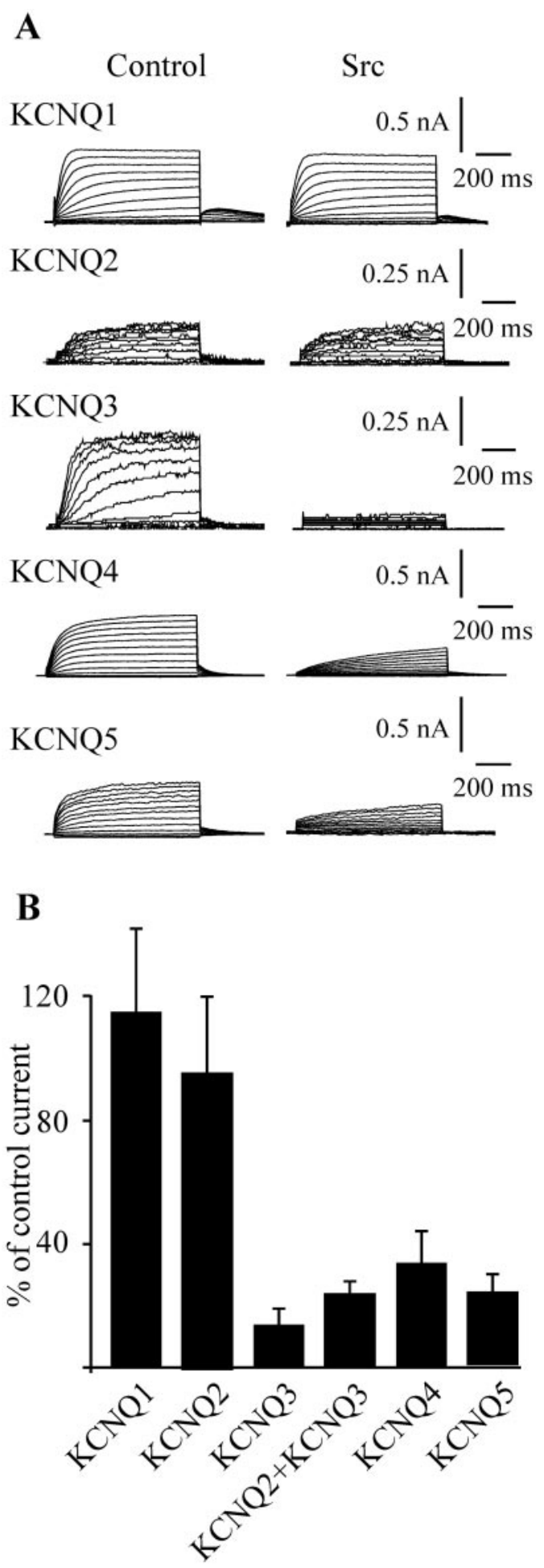

Figure 7. Src action is subunit-specific. $A$, Current traces recorded as in Figure $1 A$ from cells individually transfected with $\mathrm{KCNQ1-5}$ (as indicated) without (left traces) or together with wild-type Src (right traces). B, Mean suppression of KCNQ current density at $0 \mathrm{mV}$ by Src cotransfection expressed as a percentage of the appropriate control current $\left[\left(I_{\text {src }} / I_{\text {control }}\right) \times 100 \%\right]$. The data for pooled KCNQ2/3 are also shown for comparison. The number of experiments for each condition is given in Table 1 .

Among KCNQ1-5, Src acts on KCNQ3, KCNQ4, and KCNQ5 but spares KCNQ1 and KCNQ2. The lack of effect of Src on KCNQ2 homomultimers suggests that its actions on KCNQ2/3 heteromultimers and on SCG M current localize to the KCNQ3 subunits in the tetrameric channel.
A

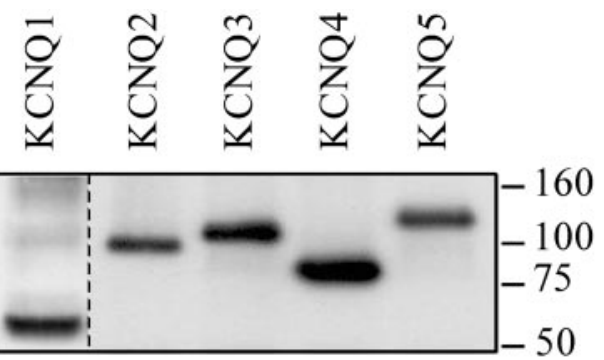

B

\begin{tabular}{|l|l|l|l|l|l|l|l|l|l|l|l|l|l|}
\hline KCNQ & 1 & 1 & 2 & 2 & 3 & 3 & 3 & 4 & 4 & 4 & 5 & 5 & 5 \\
\hline Src & & $\bullet$ & & $\bullet$ & & $\bullet$ & & & $\bullet$ & & & $\bullet$ & \\
\hline K298MSrc & & & & & & & $\bullet$ & & & $\bullet$ & & & $\bullet$ \\
\hline
\end{tabular}
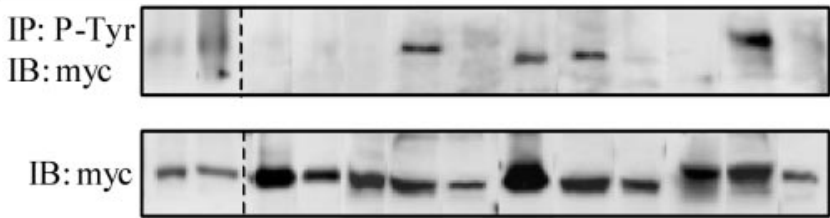

Figure 8. KCNQ3, KCNQ4, and KCNQ5 but not KCNQ1 or KCNQ2 display tyrosine phosphorylation in the presence of Src. A, Immunoblot detection of myc-tagged KCNQ2, KCNQ3, KCNQ4, and KCNQ5 and wild-type KCNQ1 proteins in CHO cells. Lysate proteins were separated by SDS-PAGE, transferred to nitrocellulose, and probed with anti-myc or anti-KCNQ1 antibodies. $B$, Top panel, Immunoprecipitation and detection by immunoblots of phosphotyrosine signals associated with KCNQ proteins. CHO cells were transfected with myc-tagged KCNQ2-5 or wild type KCNQ1 with or without (as indicated in the table at top) wild-type or K298M Src. Lysate proteins were immunoprecipitated with anti-phosphotyrosine antibodies; the immunoprecipitates were run as Western blot gels; and the resulting immunoblots were probed with anti-myc or anti-KCNQ1 antibodies. The bands for each channel with or without Src are taken from the same original film. Bottom panel, Immunoblots with anti-myc (or anti-KCNQ1) antibodies from the same lysates as in the top panel before immunoprecipitation.

\section{Modulation of KCNQ channels by c-Src is via tyrosine phosphorylation}

The experiments with tyrosine kinase and phosphatase inhibitors and kinase-dead Src strongly suggested that the effect of Src on KCNQ channels involves tyrosine phosphorylation. To test whether the five different KCNQ channels are associated with tyrosine phosphorylation by Src, we used a strategy involving immunoprecipitations, followed by immunoblotting. KCNQ2-5 subunits were epitope-tagged by introduction of the myc epitope to their $\mathrm{N}$ termini (see Materials and Methods) and individually expressed in CHO cells. Current properties of KCNQ2-5 channels were not affected by introduction of the myc epitope (data not shown). We were not able to construct myc-tagged KCNQ1 and so used the wild-type channel. In the immunoprecipitation and immunoblot experiments presented next, we used myctagged KCNQ2-5 channels in combination with anti-myc antibodies and wild-type KCNQ1 with an anti-KCNQ1 antibody. In immunoblots prepared from whole-cell lysates of $\mathrm{CHO}$ cells individually transfected with the five different KCNQ channels, these antibodies specifically labeled KCNQ1-5 at their appropriate molecular weights of $\sim 60 \mathrm{kDa}$ for KCNQ1, $100 \mathrm{kDa}$ for KCNQ2, $110 \mathrm{kDa}$ for KCNQ3, $80 \mathrm{kDa}$ for KCNQ4, and $125 \mathrm{kDa}$ for KCNQ5 (Fig. $8 \mathrm{~A}$ ).

$\mathrm{CHO}$ cells were cotransfected with myc-tagged KCNQ2-5 or with wild-type KCNQ1 channels with or without wild-type 
or K298M Src. Tyrosine-phosphorylated proteins were then immunoprecipitated with anti-phosphotyrosine antibodies; the immunoprecipitates were separated using SDS-PAGE; and the immunoblots were probed with anti-myc (or antiKCNQ1) antibodies. Consistent with the patch-clamp data (Fig. 7 ), neither KCNQ1 nor myc-tagged KCNQ2 was precipitated by the phosphotyrosine antibodies from control cells or from cells overexpressing Src. In contrast, proteins of the appropriate molecular weight for KCNQ3-5 were immunoprecipitated from cells expressing myc-tagged KCNQ3 and Src, myc-tagged KCNQ4 and Src, and myc-tagged KCNQ5 and Src (Fig. 8 B, top panel), suggesting phosphorylation associated with these channels by Src activity. KCNQ4 showed a phosphotyrosine signal even without Src cotransfection, consistent with the ability of vanadate to mimic Src overexpression (Fig. 3), with the detection of modest endogenous Src using immunoblots from non-Srctransfected $\mathrm{CHO}$ cells and with the modest run-up of KCNQ2/3 currents in non-Src-transfected cells (Fig. 2D). No subunit-specific phosphotyrosine signal was detected when KCNQ3, KCNQ4, or KCNQ5 was coexpressed with kinase-dead K298M Src. Figure 8B, bottom panel, shows immunoblots performed using the same wholecell lysates as those used in the top panel but without any immunoprecipitation. Proteins specific for KCNQ1-5 were always strongly detected in such experiments. The experiments shown in Figure 8 were reproduced three to five times for each individual KCNQ subunit. Thus, we detect a phosphotyrosine signal associated with KCNQ3, KCNQ4, and KCNQ5 but not KCNQ1 and KCNQ2. The phosphorylation is more profound if Src is overexpressed in the cells and wholly absent if a kinase-dead Src is overexpressed instead, strongly suggesting that the tyrosine phosphorylation observed is Src-dependent.

The suppression of KCNQ current amplitude by Src overexpression described in this work could be attributable to a reduction of channel activity (i.e., open probability) or a reduction in channel number. Although the rapid time course of the reversal of the current suppression by Src inhibitors suggests the former, we tested the possibility that Src suppresses KCNQ currents by altering channel expression. We used immunofluorescence to measure the expression of a myc-tagged $\mathrm{KCNQ} 3$ protein in $\mathrm{CHO}$ cells with or without Src cotransfection. Cells were immunostained with anti-myc antibodies (see Materials and Methods), and confocal images were taken. Densitometry of the confocal micrographs was used to semiquantitatively evaluate channel abundance. Shown in Figure $9 A$ are examples of such micrographs obtained with myc-tagged KCNQ3 transfected cells (top) and mycKCNQ3- and Src-transfected cells (bottom). Figure $9 B$ shows the summary of such densitometry data from control ( $m y c-K C N Q 3$; $n=9)$ and Src-cotransfected ( $m y c-K C N Q 3+S r c ; n=7)$ cells. These experiments revealed no difference in KCNQ3 protein abundance between control and Src-overexpressing cells. Although the approach used cannot precisely distinguish between KCNQ channels located in the plasma membrane and those localized subcellularly (nor can it rule out the theoretical possibility that Src action alters the single-channel conductance of the channels), these data are more consistent with the Src effect on current amplitude being caused by suppression of channel activity.

\section{Does c-Src mediate muscarinic modulation of KCNQ channels?}

Several members of the KCNQ channel family are best known for their modulation by muscarinic receptor agonists. Such modulation requires $\mathrm{G}_{\mathrm{q} / 11} \alpha$ subunits and an as yet unidentified diffusible
A

B

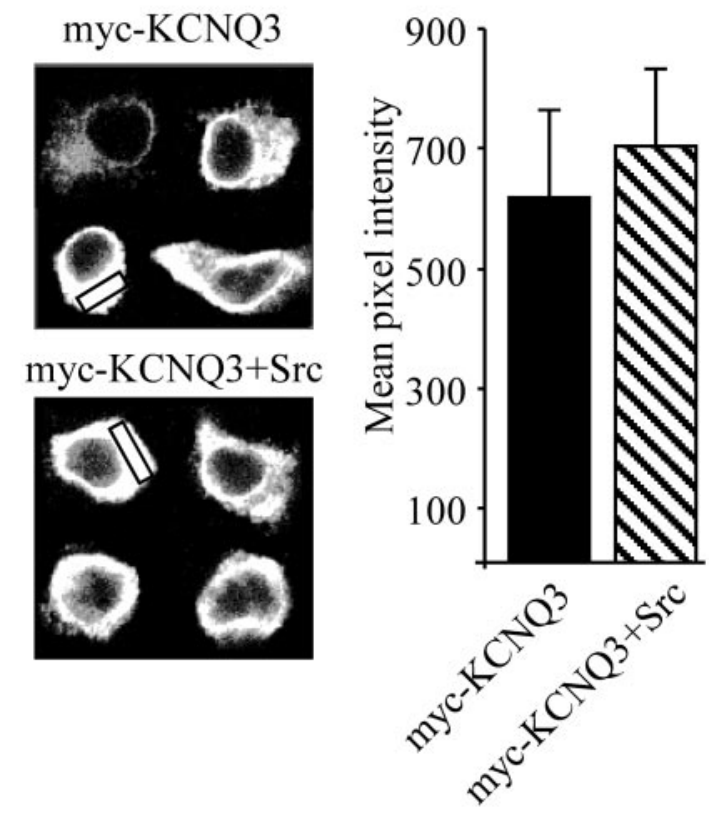

Figure 9. Src does not suppress KCNQ3 currents by inhibiting KCNQ3 protein abundance. $A$, Confocal images of cells transfected with myc-tagged KCNQ3 without (KCNQ3) or together with $(K C N Q 3+S r c)$ Src and immunostained with anti-myc antibodies. B, Summarized densitometry data from the confocal images as in $A$. Fluorescence is expressed as mean pixel intensity. Black boxes in $A$ indicate areas where pixel intensity was calculated. For myc-KCNQ3, $n=9$; for $m y c-K C N Q 3+S r c, n=7$.

cytosolic messenger (Selyanko et al., 1992, 2000). Thus, it was important to determine whether Src might be the unidentified messenger and whether Src action is a part of the muscarinic signal. To test such involvement of Src, KCNQ2 and KCNQ3 were coexpressed in $\mathrm{CHO}$ cells together with $\mathrm{M}_{1}$ muscarinic receptors and wild-type or kinase-dead K298M Src, and the ability of a muscarinic agonist to inhibit the KCNQ2/3 current was assayed. As for cells not cotransfected with the $M_{1}$ receptor, Src suppressed current amplitudes and slowed activation kinetics, and K298M Src was without effect. For cells transfected with KCNQ2, KCNQ3, and $\mathrm{M}_{1}$ receptors but not Src, the current density and $\tau_{\text {act }}($ at $0 \mathrm{mV})$ were $55.3 \pm 12.3 \mathrm{pA} / \mathrm{pF}$ and $140 \pm 21 \mathrm{msec}$ $(n=7)$; for cells cotransfected with $\mathrm{Src}$, they were $13.4 \pm 4.9$ $\mathrm{pA} / \mathrm{pF}(p \leq 0.01)$ and $293 \pm 26 \mathrm{msec}(p \leq 0.001 ; n=6)$; and for cells transfected with $\mathrm{K} 298 \mathrm{M} \mathrm{Src}$, they were $54.1 \pm 11.0 \mathrm{pA} / \mathrm{pF}$ and $148 \pm 24 \mathrm{msec}(n=7)$.

Shown in Figure $10 \mathrm{~A}$ are experiments demonstrating muscarinic modulation of KCNQ2/3 currents by bath application of the muscarinic agonist oxo-M $(10 \mu \mathrm{M})$. We used the $\mathrm{Ca}^{2+}$-clamping mixture pipette solution in these experiments to exclude an influence of cytosolic $\mathrm{Ca}^{2+}$ on the current (Shapiro et al., 2000). After 1-2 min of recording of the control current, oxo-M was bath-applied, and the inhibition of the current was observed. We found that oxo-M suppressed the KCNQ2/3 current equally well in cells not cotransfected with Src (Fig. 10A, left panel) or cotransfected with wild-type Src (Fig. 10 A, middle panel) or K298M kinase-dead Src (Fig. 10 A, right panel). In these three groups, the muscarinic inhibition values of the KCNQ2/3 current by oxo-M were $79 \pm 9 \%(n=7), 83 \pm 8 \%(n=$ $6)$, and $92 \pm 6 \%(n=7)$, respectively.

To further test for involvement of Src in mAchR-mediated suppression of KCNQ2/3 currents, we tested whether Src inhibitors 

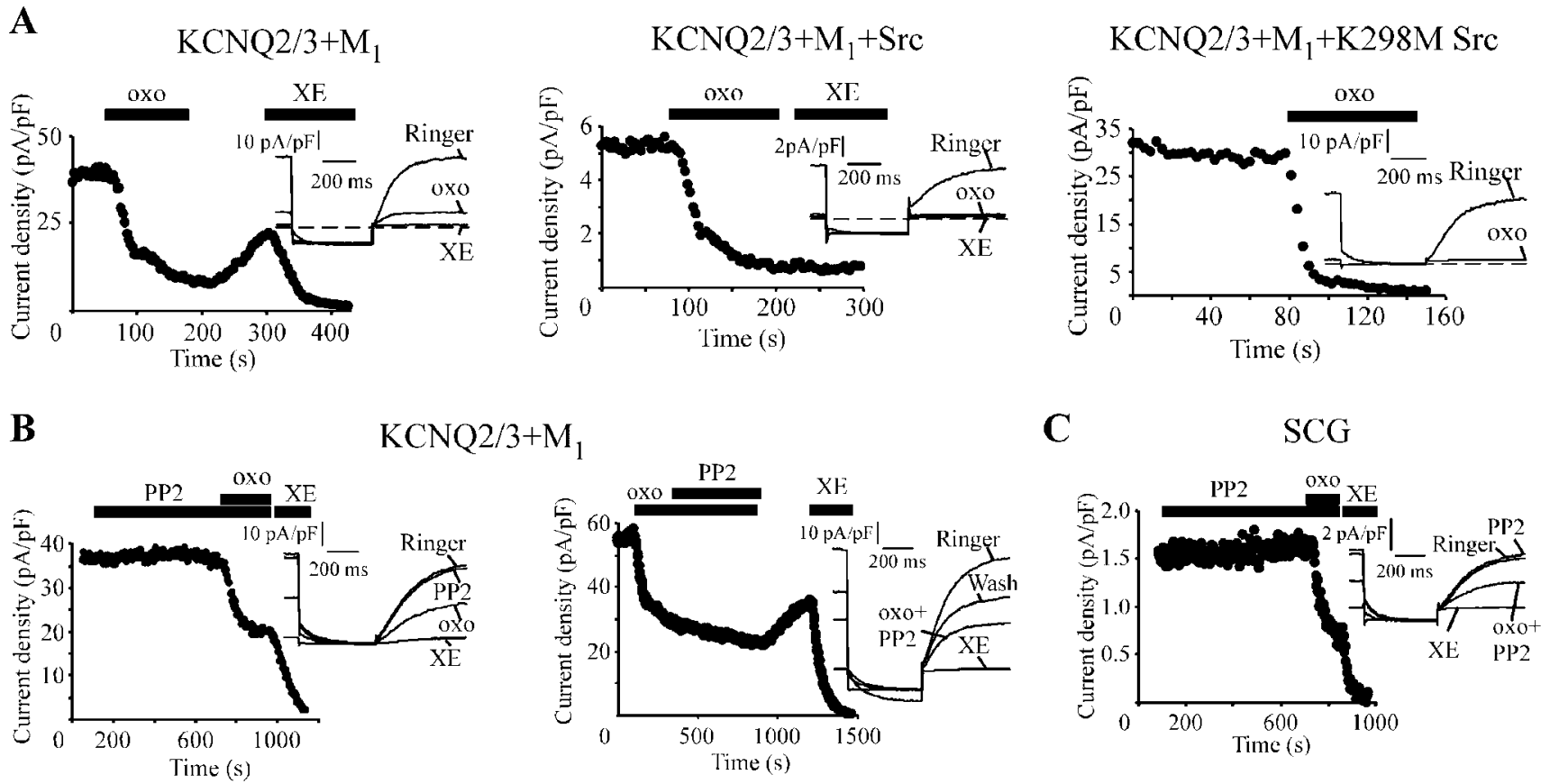

Figure 10. Src action is distinct from muscarinic modulation of KCNQ2/3 and M currents. $A$, $C H O$ cells were cotransfected with KCNQ2, KCNQ3, and $M_{1}$ muscarinic receptors, either alone (left panel) or together with wild-type (middle panel) or K298M (right panel) Src. Plotted are the current densities measured at $0 \mathrm{mV}$ using a 500 msec voltage pulse to - $60 \mathrm{mV}$, followed by a $650 \mathrm{msec}$ pulse back to the holding potential of $0 \mathrm{mV}$, given every $3 \mathrm{sec}$. Oxotremorine (oxo; $10 \mu \mathrm{M})$ and XE991 (XE; $50 \mu \mathrm{M})$ were bath-applied during the times shown by the bars. Insets, Currents at the indicated times during the experiments. The dotted lines indicate the zero current level. B, C, Src inhibitors do not block or reverse muscarinic modulation of KCNQ2/3 and M currents. B, Plotted are current densities at $0 \mathrm{mV}$ from the voltage protocol as in $A$ from CHO cells cotransfected with KCNQ2, KCNQ3, and M, receptors (but not Src). Oxo (10 $\mu \mathrm{m}$ ), PP2 (200 nM), and XE991 (50 $\mu \mathrm{m}$ ) were bath-applied during the periods shown by their respective bars. Insets, currents at the indicated times during the experiments. C, $M$ current densities measured from the amplitude of the time-dependent deactivating relaxations at $-60 \mathrm{mV}$ in an uninfected $\mathrm{SCG}$ neuron. The cell was held at $-25 \mathrm{mV}$ and a $500 \mathrm{msec}$ step to $-60 \mathrm{mV}$, followed by a $650 \mathrm{msec}$ step back to $-25 \mathrm{mV}$, given every 3 sec under continuous bath perfusion. 0xo (10 $\mu \mathrm{M})$, PP2 (200 nM), and XE991 $(50 \mu \mathrm{m})$ were bath-applied during the periods shown by their respective bars.

could prevent or reverse muscarinic modulation. Shown in Figure $10 \mathrm{~B}$, left panel, is an experiment in which a $\mathrm{CHO}$ cell transfected with KCNQ2/3 but not with Src was pretreated with PP2 and then oxo-M was applied. Similar to the effect of PP2 on the non-Src-transfected cell shown in Figure 2D, we observed a modest run-up of the current during PP2 application, consistent with blockade of endogenous Src-like activity on the channels. However, PP2 was unable to prevent subsequent inhibition of KCNQ2/3 current by oxo-M. Application of oxo-M to such $\mathrm{CHO}$ cells pretreated with PP2 (10-15 min) resulted in the inhibition of $\mathrm{KCNQ} 2 / 3$ current by $60 \pm 7 \%(n=5)$, a value indistinguishable from that of cells preincubated with PP3 ( $63 \pm 8 \% ; n=3$; data not shown). We also asked whether PP2 or erbstatin could reverse muscarinic modulation. Neither PP2 (Fig. $10 \mathrm{~B}$, right panel; $n=3)$ nor erbstatin $(n=3$; data not shown) reversed muscarinic modulation of the KCNQ2/3 current after oxo-M had been applied. We also performed experiments of this kind on M current in SCG neurons. SCG cells were preincubated with erbstatin or with PP2, and the ability of oxo-M to subsequently inhibit $\mathrm{M}$ current was assayed. A representative experiment using PP2 is shown in Fig. 10C, demonstrating unaltered modulation of $\mathrm{M}$ current by the Src inhibitor. For SCG cells pretreated with erbstatin or with PP2, oxo-M subsequently inhibited the M current by $86 \pm$ $3 \%(n=3)$ and $76 \%(n=2)$, respectively, inhibitions indistinguishable from those in control cells $(82 \pm 3 \%$; $n=6)$. As for the experiments on KCNQ2/3 channels in CHO cells, neither PP2 $(n=3)$ nor erbstatin $(n=3)$ reversed muscarinic modulation of M current in SCG neurons after application of oxo-M (data not shown). Thus, we conclude that Src and muscarinic receptors use different pathways for KCNQ and M current modulation.

\section{Discussion}

In this work, we describe a novel pathway of KCNQ and M-type $\mathrm{K}^{+}$channel regulation by Src-dependent tyrosine phosphorylation. We show that Src acts both in a heterologous expression system using cloned channels and on native $\mathrm{M}$ channels in primary sympathetic neurons. The actions of Src were subunitspecific. Thus, Src strongly suppressed current amplitudes from, and slowed activation kinetics of, KCNQ3, KCNQ4, and KCNQ5 homomultimers, as well as KCNQ2/3 heteromultimers and $\mathrm{M}$ current, but wholly spared KCNQ1 and KCNQ2 homomultimers. The strongest effect of Src was on KCNQ3 channels, whose activity is profoundly inhibited by Src overexpression (Table 1, Fig. 7). The lack of action on KCNQ2 channels suggests that Src effects on KCNQ2/3 heteromultimers and on M current are likely attributable to an action solely on the KCNQ3 subunits of the channel tetramers. We found that suppression of the current amplitude in all Src-sensitive channels was always accompanied by slowing of the activation kinetics, possibly indicating that both effects localize to the same site of Src action on the channels.

Several lines of evidence demonstrate that the effect of Src is mediated by tyrosine phosphorylation: (1) all the observed effects of Src (suppression of current amplitude, slowing of activation, and shift of voltage dependence) were mostly reversed by the tyrosine kinase inhibitors erbstatin and PP2; (2) the tyrosine phosphatase inhibitor vanadate fully mimicked all the effects of Src; (3) use of the Src K298M point mutant that abolishes kinase activity, but not Src binding to substrates, was without any effect on KCNQ2/3 currents; and (4) KCNQ3, KCNQ4, and KCNQ5 (the subunits that were modulated by $\mathrm{Src}$ in our patch-clamp 
experiments) were associated with phosphotyrosine signals when coexpressed with Src. In contrast, KCNQ1 and KCNQ2, which did not respond to Src overexpression in patch-clamp experiments, were never associated with a phosphotyrosine signal. Interestingly, KCNQ4 displayed a phosphotyrosine signal even without Src overexpression (Fig. $8 B$ ). The phosphorylation signal became stronger in Src-overexpressing cells and was absent when the kinase-dead K298M Src (which serves as dominant negative in this case) was overexpressed instead of wild-type Src (Fig. 8 B). Such experiments further support our interpretation of the effect of Src inhibitors and of vanadate on the KCNQ2/3 currents in non-Src-transfected cells as being attributable to modest tonic Src-like activity in $\mathrm{CHO}$ cells. Taken together, these data suggest that the effects of Src on KCNQ3-5 channels are attributable to tyrosine phosphorylation of the channel proteins, although we cannot rule out that Src acts via phosphorylation of physically associated adaptor proteins that can be coimmunoprecipitated with the channels.

There are several examples of Src actions on $\mathrm{K}^{+}$channels known from the literature. The closest analogy to this study is with Src modulation of Shaker family (Kv1) channels. It has been shown that Src family tyrosine kinases strongly modulate Kv1.3 (Holmes et al., 1996a), Kv1.4, and Kv1.5 (Holmes et al., 1996b; Nitabach et al., 2001) channels. For the case of Kv1.3, overexpression of constitutively active viral Src phosphorylates, suppresses current amplitudes, and alters kinetics (Fadool et al., 1997). For the case of Kv1.4 and Kv1.5, Src appears to have dual actions: suppression of current amplitudes via binding (without requisite phosphorylation) to Kv1.5 subunits as homomultimers, or as heteromultimers with Kv1.4, and modulation of kinetics of Kv1.4 homomultimers via tyrosine phosphorylation (without requisite binding; Nitabach et al., 2001; Nitabach et al., 2002). Our results with KCNQ2/3 and M current are similar in that our data suggest that Src acts on the heteromeric channel by acting on only one type of subunit (KCNQ3). For Kv1.4 and Kv1.5 channels, however, the effects on current amplitudes and on kinetics seem to be attributable to distinct actions on the channels, the former mostly from Src binding to proline-rich Src homology 3 (SH3)-binding domains of Kv1.5 and the latter apparently by direct tyrosine phosphorylation of Kv1.4 (Nitabach et al., 2001; Nitabach et al., 2002). This does not seems to be the case here for KCNQ channels, because the tyrosine kinase and phosphatase inhibitors affected both current amplitude and kinetics, and the kinase-dead Src had none of these effects. There has been a study implying tyrosine kinase-mediated augmentation of KCNQ2 currents (kinase inhibitors decreased the current; Jow and Wang, 2000), but the mechanism underlying their data are unclear.

Sequence gazing of KCNQ3-5 does not reveal the existence of preferred proline-rich SH3-binding domains (RPLPXXP), preferred SH2-binding domains (pYEEI), or the optimum tyrosine substrate sequence (EEEIY $/{ }_{\mathrm{E}} \mathrm{EFD}$; for review, see Tatosyan and Mizenina, 2000). However, all three channels contain the minimum PXXP sequence for binding to $\mathrm{SH} 3$ domains, and the sequence around Src-phosphorylated tyrosines can be highly variable (Hubbard and Till, 2000). Future work will identify the molecular determinants of the Src actions described here and whether they suggest novel Src-interacting motifs in KCNQ3-5 channels or variants of those already described.

Modulation of KCNQ3-5 by Src seems to be unrelated to the well studied pathway of M-type channel modulation by mAchRs. This conclusion comes from our results showing that muscarinic agonists inhibit Src-modulated channels, and that expression of the kinase-dead Src had no effect on muscarinic modulation. In addition, Src inhibitors failed to prevent or reverse such modulation (Fig. 10). Also arguing against involvement of Src in muscarinic modulation of KCNQ channels is that KCNQ1 and KCNQ2 are both well modulated by muscarinic stimulation (Selyanko et al., 2000; Shapiro et al., 2000) but not by Src (Table 1, Fig. 7). It is important to note that we were able to reproduce our data obtained with the heterologous expression system on native $\mathrm{M}$ current in SCG neurons. It is now thought that combinations of heteromeric KCNQ2/3 and KCNQ3/5 and homomeric KCNQ3-5 channels can underlie the heterogeneity of M-type currents (Wang et al., 1998; Cooper et al., 2000; Lerche et al., 2000; Robbins, 2001; Roche et al., 2002). The modulation of M-type $\mathrm{K}^{+}$channels by Src reported here might therefore be an important mechanism of regulation of neuronal excitability. Thus, not only do mutations in KCNQ2 and KCNQ3 genes lead to a form of inherited epilepsy (for review, see Jentsch, 2000), but also, an increase in Src kinase activity was found on induction of spontaneous epileptiform activity in rat hippocampus (Sanna et al., 2000). Indeed, in that study, the epileptiform activity could be strongly reduced by the Src inhibitor PP2.

What physiological signals are we observing by using Src overexpression or tyrosine phosphatase blockade? The Src family of nonreceptor tyrosine kinases has been shown to be activated by both G-protein-coupled receptors (GPCRs) and receptor tyrosine kinases (RTKs), to be a signaling intermediary between both GPCRs and RTKs, and to be involved in downstream activation of the MAP kinase signaling cascade by both types of receptors (Diverse-Pierluissi et al., 1997; Luttrell et al., 1997, 1999; Pierce et al., 2001). Indeed, of strongest relevance to sympathetic neurons, both mAchRs and the nerve growth factor (NGF) receptor TrkA activate Src (for review, see Abram and Courtneidge, 2000). NGF, which is required for growth, survival, and differentiation of sympathetic neurons, is a member of the neurotrophin family that has both acute effects on synaptic transmission and plasticity (Schinder and Poo, 2000) as well as the long-term effects common among growth factor receptors (Barbacid, 1993). Thus, our effects of Src overexpression may constitute a "shortcut" in both acute and long-lasting signals triggered by growth factors or GPCR agonists, and the relatively rapid actions on M-type channels described here may constitute one mechanism by which tyrosine kinases acutely regulate neuronal excitability. Future work will ask whether Src overexpression indeed mimics stimulation of receptor tyrosine kinases and will seek to probe the biophysical mechanisms of the modulation of this family of $\mathrm{K}^{+}$ channels by tyrosine kinases in general.

\section{References}

Abram CL, Courtneidge SA (2000) Src family tyrosine kinases and growth factor signaling. Exp Cell Res 254:1-13.

Al-Khalili O, Duke BJ, Zeltwanger S, Eaton DC, Spier B, Stockand JD (2001) Cloning of the proto-oncogene c-src from rat testis. DNA Sequence 12:425-429.

Barbacid M (1993) Nerve growth factor: a tale of two receptors. Oncogene 8:2033-2042.

Bernheim L, Beech DJ, Hille B (1991) A diffusible second messenger mediates one of the pathways coupling receptors to calcium channels in rat sympathetic neurons. Neuron 6:859-867.

Biervert C, Schroeder BC, Kubisch C, Berkovic SF, Propping P, Jentsch TJ, Steinlein OK (1998) A potassium channel mutation in neonatal human epilepsy. Science 279:403-406.

Brown DA, Adams PR (1980) Muscarinic suppression of a novel voltagesensitive $\mathrm{K}^{+}$current in a vertebrate neurone. Nature 283:673-676.

Cayabyab FS, Schlichter LC (2002) Regulation of an ERG K ${ }^{+}$current by Src tyrosine kinase. J Biol Chem 277:13673-13681.

Cayabyab FS, Khanna R, Jones OT, Schlichter LC (2000) Suppression of the 
rat microglia Kv1.3 current by src-family tyrosine kinases and oxygen/ glucose deprivation. Eur J Neurosci 12:1949-1960.

Charlier C, Singh NA, Ryan SG, Lewis TB, Reus BE, Leach RJ, Leppert M (1998) A pore mutation in a novel KQT-like potassium channel gene in an idiopathic epilepsy family. Nat Genet 18:53-55.

Constanti A, Brown DA (1981) M-Currents in voltage-clamped mammalian sympathetic neurones. Neurosci Lett 24:289-294.

Cooper EC, Aldape KD, Abosch A, Barbaro NM, Berger MS, Peacock WS, Jan YN, Jan LY (2000) Colocalization and coassembly of two human brain M-type potassium channel subunits that are mutated in epilepsy. Proc Natl Acad Sci USA 97:4914-4919.

Coucke PJ, Hauwe PV, Kelley PM, Kunst H, Schatteman I, Velzen DV, Meyers J, Ensink RJ, Verstreken M, Declau F, Marres H, Kastury K, Bhasin S, McGuirt WT, Smith RJ, Cremers CW, Heyning PV, Willems PJ, Smith SD, Camp GV (1999) Mutations in the KCNQ4 gene are responsible for autosomal dominant deafness in four DFNA2 families. Hum Mol Genet 8:1321-1328.

Diverse-Pierluissi M, Remmers AE, Neubig RR, Dunlap K (1997) Novel form of crosstalk between $\mathrm{G}$ protein and tyrosine kinase pathways. Proc Natl Acad Sci USA 94:5417-5421.

Fadool DA, Holmes TC, Berman K, Dagan D, Levitan IB (1997) Tyrosine phosphorylation modulates current amplitude and kinetics of a neuronal voltage-gated potassium channel. J Neurophysiol 78:1563-1573.

Felsch JS, Cachero TG, Peralta EG (1998) Activation of protein tyrosine kinase PYK2 by the $\mathrm{m} 1$ muscarinic acetylcholine receptor. Proc Natl Acad Sci USA 95:5051-5056.

Hille B (2001) Ion channels of excitable membranes, Ed 3. Sunderland, MA: Sinauer.

Holmes TC, Fadool DA, Levitan IB (1996a) Tyrosine phosphorylation of the Kv1.3 potassium channel. J Neurosci 16:1581-1590.

Holmes TC, Fadool DA, Ren R, Levitan IB (1996b) Association of Src tyrosine kinase with a human potassium channel mediated by $\mathrm{SH} 3$ domain. Science 274:2089-2091.

Holt JR, Corey DP (1999) Ion channel defects in hereditary hearing loss. Neuron 22:217-219.

Huang XY, Morielli AD, Peralta EG (1993) Tyrosine kinase-dependent suppression of a potassium channel by the $\mathrm{G}$ protein-coupled $\mathrm{m} 1$ muscarinic acetylcholine receptor. Cell 75:1145-1156.

Hubbard SR, Till JH (2000) Protein tyrosine kinase structure and function. Annu Rev Biochem 69:373-398.

Igishi T, Gutkind JS (1998) Tyrosine kinases of the Src family participate in signaling to MAP kinase from both $\mathrm{G}_{\mathrm{q}}$ - and $\mathrm{G}_{\mathrm{i}}$-coupled receptors. Biochem Biophys Res Commun 244:5-10.

Jentsch TJ (2000) Neuronal KCNQ potassium channels: physiology and role in disease. Nat Rev Neurosci 1:21-30.

Jow F, Wang K (2000) Cloning and functional expression of rKCNQ2 $\mathrm{K}^{+}$ channel from rat brain. Brain Res Mol Brain Res 80:269-278.

Kharkovets T, Hardelin JP, Safieddine S, Schweizer M, El-Amraoui A, Petit C, Jentsch TJ (2000) KCNQ4, a K ${ }^{+}$channel mutated in a form of dominant deafness, is expressed in the inner ear and the central auditory pathway. Proc Natl Acad Sci USA 97:4333-4338.

Kubisch C, Schroeder BC, Friedrich T, Lutjohann B, El-Amraoui A, Marlin S, Petit C, Jentsch TJ (1999) KCNQ4, a novel potassium channel expressed in sensory outer hair cells, is mutated in dominant deafness. Cell 96:437-446.

Lerche C, Scherer CR, Seebohm G, Derst C, Wei AD, Busch AE, Steinmeyer K (2000) Molecular cloning and functional expression of KCNQ5, a potassium channel subunit that may contribute to neuronal M-current diversity. J Biol Chem 275:22395-22400.

Ling S, Woronuk G, Sy L, Lev S, Braun AP (2000) Enhanced activity of a large conductance, calcium-sensitive $\mathrm{K}^{+}$channel in the presence of Src tyrosine kinase. J Biol Chem 275:30683-30689.

Luttrell LM, van Biesen T, Hawes BE, Koch WJ, Krueger KM, Touhara K, Lefkowitz RJ (1997) G-protein-coupled receptors and their regulation: activation of the MAP kinase signaling pathway by G-protein-coupled receptors. Adv Second Messenger Phosphoprotein Res 31:263-277.

Luttrell LM, Daaka Y, Lefkowitz RJ (1999) Regulation of tyrosine kinase cascades by G-protein-coupled receptors. Curr Opin Cell Biol 11:177-183.

Ma YC, Huang XY (2002) Novel regulation and function of Src tyrosine kinase. Cell Mol Life Sci 59:456-462.

Miller WE, Maudsley S, Ahn S, Khan KD, Luttrell LM, Lefkowitz RJ (2000) beta-arrestin 1 interacts with the catalytic domain of the tyrosine kinase
c-SRC: role of beta-arrestin1-dependent targeting of c-SRC in receptor endocytosis. J Biol Chem 275:11312-11319.

Nitabach MN, Llamas DA, Araneda RC, Intile JL, Thompson IJ, Zhou YI, Holmes TC (2001) A mechanism for combinatorial regulation of electrical activity: potassium channel subunits capable of functioning as Src homology 3-dependent adaptors. Proc Natl Acad Sci USA 98:705-710.

Nitabach MN, Llamas DA, Thompson IJ, Collins KA, Holmes TC (2002) Phosphorylation-dependent and phosphorylation-independent modes of modulation of shaker family voltage-gated potassium channels by SRC family protein tyrosine kinases. J Neurosci 22:7913-7922.

Pierce KL, Luttrell LM, Lefkowitz RJ (2001) New mechanisms in heptahelical receptor signaling to mitogen activated protein kinase cascades. Oncogene 20:1532-1539.

Robbins J (2001) KCNQ potassium channels: physiology, pathophysiology, and pharmacology. Pharmacol Ther 90:1-19.

Roche JP, Westenbroek R, Sorom AJ, Hille B, Mackie K, Shapiro MS (2002) Antibodies and a cysteine-modifying reagent show correspondence of $\mathrm{M}$ current in neurons to KCNQ2 and KCNQ3 $\mathrm{K}^{+}$channels. Br J Pharmacol, in press.

Sanguinetti MC, Curran ME, Zou A, Shen J, Spector PS, Atkinson DL, Keating MT (1996) Coassembly of K(V)LQT1 and $\operatorname{minK}$ (IsK) proteins to form cardiac I(Ks) potassium channel. Nature 384:80-83.

Sanna PP, Berton F, Cammalleri M, Tallent MK, Siggins GR, Bloom FE, Francesconi W (2000) A role for Src kinase in spontaneous epileptiform activity in the CA3 region of the hippocampus. Proc Natl Acad Sci USA 97:8653-8657.

Schinder AF, Poo M (2000) The neurotrophin hypothesis for synaptic plasticity. Trends Neurosci 23:639-645.

Schroeder BC, Kubisch C, Stein V, Jentsch TJ (1998) Moderate loss of function of cyclic-AMP-modulated KCNQ2/KCNQ3 $\mathrm{K}^{+}$channels causes epilepsy. Nature 396:687-690.

Schroeder BC, Hechenberger M, Weinreich F, Kubisch C, Jentsch TJ (2000) KCNQ5, a novel potassium channel broadly expressed in brain, mediates M-type currents. J Biol Chem 275:24089-24095.

Selyanko AA, Stansfeld CE, Brown DA (1992) Closure of potassium M-channels by muscarinic acetylcholine-receptor stimulants requires a diffusible messenger. Proc R Soc Lond B Biol Sci 250:119-125.

Selyanko AA, Hadley JK, Wood IC, Abogadie FC, Jentsch TJ, Brown DA (2000) Inhibition of KCNQ1-4 potassium channels expressed in mammalian cells via $\mathrm{M}_{1}$ muscarinic acetylcholine receptors. J Physiol (Lond) 522:349-355.

Shalaby FY, Levesque PC, Yang WP, Little WA, Conder ML, Jenkins-West T, Blanar MA (1997) Dominant-negative KvLQT1 mutations underlie the LQT1 form of long QT syndrome. Circulation 96:1733-1736.

Shapiro MS, Roche JP, Kaftan EJ, Cruzblanca H, Mackie K, Hille B (2000) Reconstitution of muscarinic modulation of the KCNQ2/KCNQ3 $\mathrm{K}^{+}$ channels that underlie the neuronal M current. J Neurosci 20:1710-1721.

Singh NA, Charlier C, Stauffer D, DuPont BR, Leach RJ, Melis R, Ronen GM, Bjerre I, Quattlebaum T, Murphy JV, McHarg ML, Gagnon D, Rosales TO, Peiffer A, Anderson VE, Leppert M (1998) A novel potassium channel gene, KCNQ2, is mutated in an inherited epilepsy of newborns. Nat Genet 18:25-29.

Tatosyan AG, Mizenina OA (2000) Kinases of the Src family: structure and functions. Biochemistry 65:49-58.

Tinel N, Diochot S, Lauritzen I, Barhanin J, Lazdunski M, Borsotto M (2000) M-type KCNQ2-KCNQ3 potassium channels are modulated by the KCNE2 subunit. FEBS Lett 480:137-141.

Wang HS, Pan Z, Shi W, Brown BS, Wymore RS, Cohen IS, Dixon JE, McKinnon D (1998) KCNQ2 and KCNQ3 potassium channel subunits: molecular correlates of the M-channel. Science 282:1890-1893.

Wang Q, Curran ME, Splawski I, Burn TC, Millholland JM, VanRaay TJ, Shen J, Timothy KW, Vincent GM, de Jager T, Schwartz PJ, Toubin JA, Moss AJ, Atkinson DL, Landes GM, Connors TD, Keating MT (1996) Positional cloning of a novel potassium channel gene: KVLQT1 mutations cause cardiac arrhythmias. Nat Genet 12:17-23.

Warth R, Garcia Alzamora M, Kim JK, Zdebik A, Nitschke R, Bleich M, Gerlach U, Barhanin J, Kim SJ (2002) The role of KCNQ1/KCNE1 K ${ }^{+}$ channels in intestine and pancreas: lessons from the KCNE1 knockout mouse. Pflügers Arch 443:822-828.

Yang WP, Levesque PC, Little WA, Conder ML, Shalaby FY, Blanar MA (1997) KvLQT1, a voltage-gated potassium channel responsible for human cardiac arrhythmias. Proc Natl Acad Sci USA 94:4017-4021. 